\title{
Measurement of $\mathrm{pH}$
}

Chapter 6.4 of

Section A, National Field Manual for the Collection of Water-Quality Data Book 9, Handbooks for Water-Resources Investigations

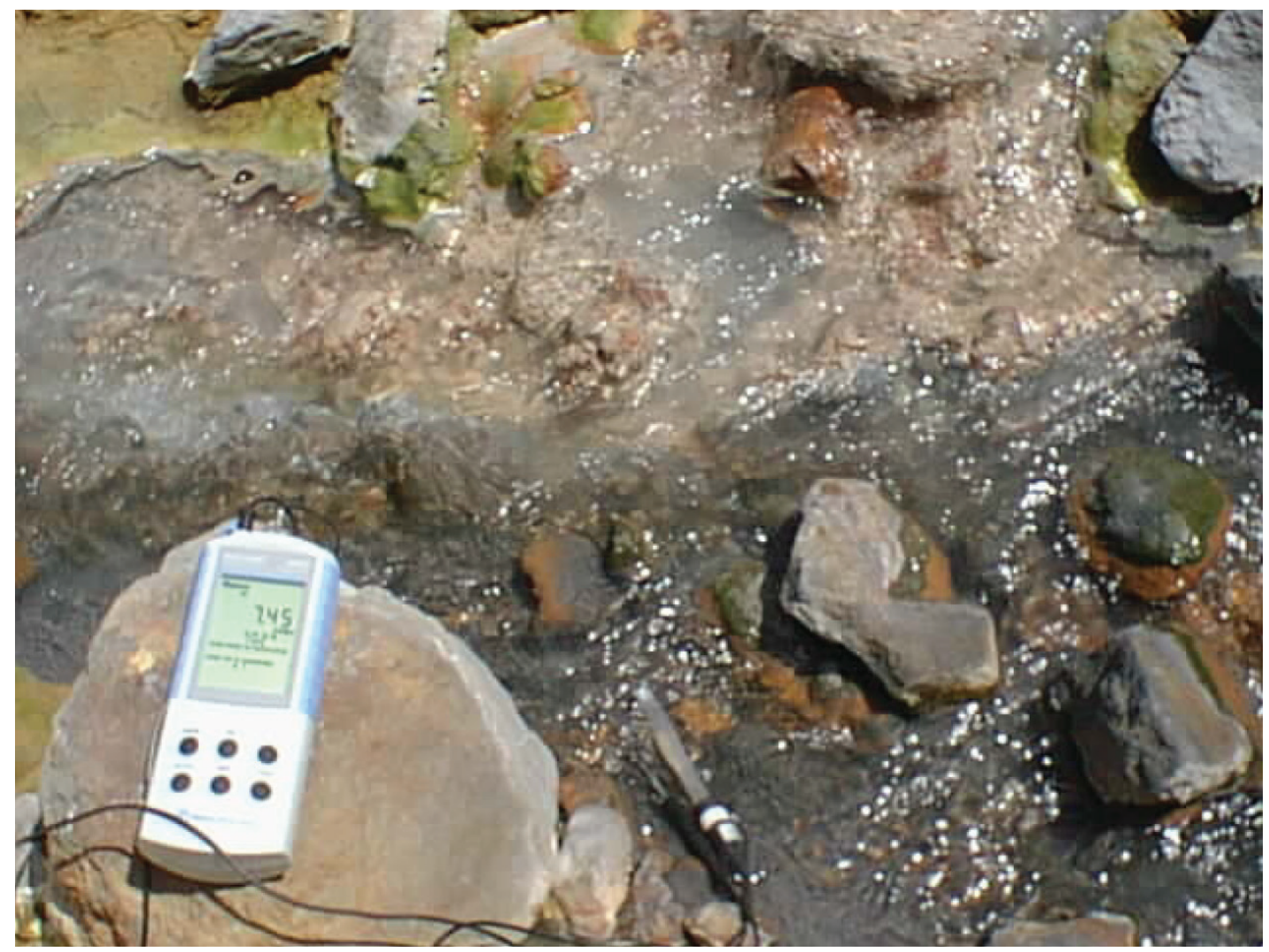

Techniques and Methods 9-A6.4

Supersedes USGS Techniques of Water-Resources Investigations, Book 9, Chapter A6.4, Version 2.0 
Cover: Measurement of $\mathrm{pH}$ in Boulder Creek, Colorado. Photograph by Phillip Verplanck, U.S. Geological Survey. 


\section{Measurement of $\mathrm{pH}$}

By U.S. Geological Survey

Chapter 6.4 of

Section A, National Field Manual for the Collection of Water-Quality Data

Book 9, Handbooks for Water-Resources Investigations

Techniques and Methods 9-A6.4

Supersedes USGS Techniques of Water-Resources Investigations,

Book 9, Chapter A6.4, Version 2.0

U.S. Department of the Interior

U.S. Geological Survey 


\section{U.S. Geological Survey, Reston, Virginia \\ First Release: April 1998, online as Techniques of Water-Resources Investigations (TWRI), book 9, chapter A6.4, Version 1.0 \\ Revised: July 2003, online as TWRI 9-A6.4, Version 1.2 \\ Revised: January 2006, online as TWRI 9-A6.4, Version 1.3 \\ Revised: October 2008, online as TWRI 9-A6.4, Version 2.0 \\ Revised: February 2021, online as Techniques and Methods, book 9, chapter A6.4}

For more information on the USGS - the Federal source for science about the Earth, its natural and living resources, natural hazards, and the environment-visit https://www.usgs.gov or call 1-888-ASK-USGS.

For an overview of USGS information products, including maps, imagery, and publications, visit https://store.usgs.gov.

Any use of trade, firm, or product names is for descriptive purposes only and does not imply endorsement by the U.S. Government.

Although this information product, for the most part, is in the public domain, it also may contain copyrighted materials as noted in the text. Permission to reproduce copyrighted items must be secured from the copyright owner.

Suggested citation:

U.S. Geological Survey, 2021, Measurement of pH: U.S. Geological Survey Techniques and Methods, book 9, chap. A6.4, 21 p., https://doi.org/10.3133/tm9A6.4. [Supersedes USGS Techniques of Water-Resources Investigations, book 9, chap. A6.4, version 2.0.]

ISSN 2328-7055 (online) 


\section{Contents}

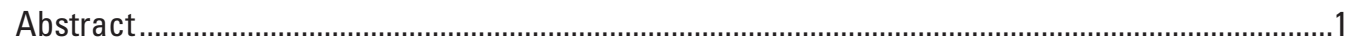

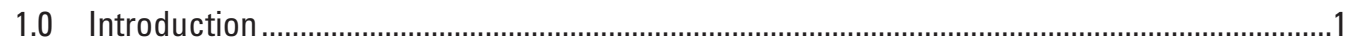

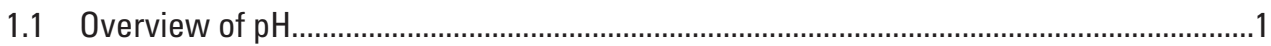

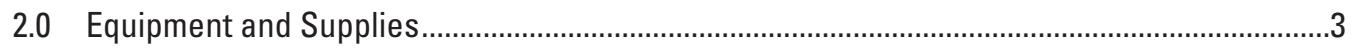

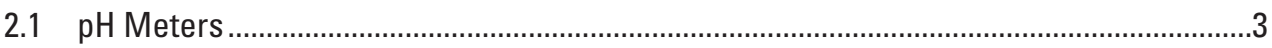

$2.2 \mathrm{pH}$ Electrodes

2.2.1 How a Combination pH Electrode Works ...........................................................

2.3 Standard pH Buffer Solutions ...................................................................................

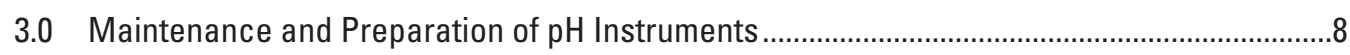

3.1 Electrode Care and Cleaning ......................................................................................

3.2 Reconditioning (Flushing and Refilling) of Liquid-Filled Electrodes.................................

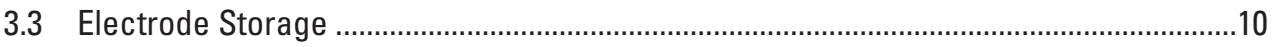

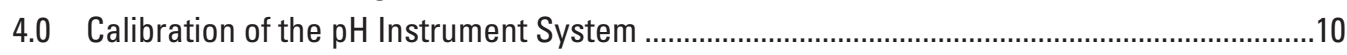

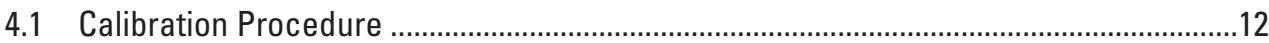

4.1.1 Calibration of a Single-Parameter Meter and pH Electrode used for Sample Measurement or an Alkalinity Titration ..............................................................12

4.1.2 Calibration of the pH Sensor in Multiparameter Sondes......................................14

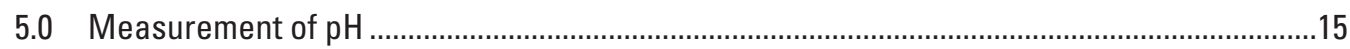

5.1 Making the $\mathrm{pH}$ Measurement .....................................................................................15

5.2 Measurement of $\mathrm{pH}$ in Waters with Low Specific Conductance....................................18

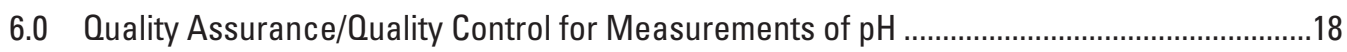

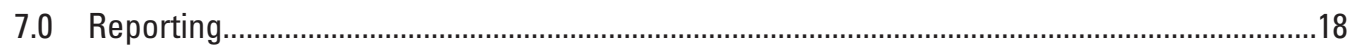

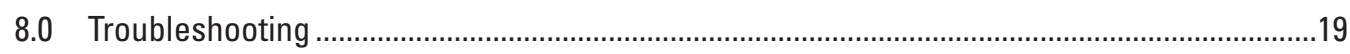

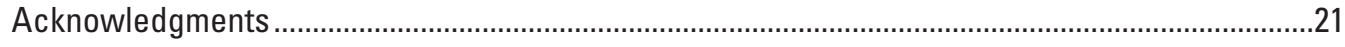

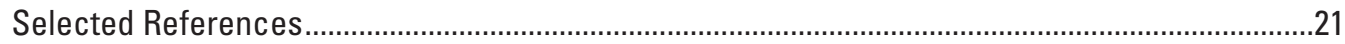

\section{Figures}

6.4-1. Diagram showing typical $\mathrm{pH}$ range of natural waters .......................................................

6.4-2. Diagram of a combination (single-junction) pH electrode ..............................................

6.4-3. Procedure: Steps for making measurements of $\mathrm{pH}$..................................................15

6.4-4. Photographs of a flow-through cell/chamber for use with multiple sensors, shown without sensors installed; and a flow-through cell for a multiparameter sonde.

\section{Tables}

6.4-1. Equipment and supplies used for measuring $\mathrm{pH}$...........................................................

6.4-2. Recommended $\mathrm{pH}$ electrodes for a variety of water types ...............................................

6.4-3. Values of $\mathrm{pH}$ from 0 to 90 degrees Celsius for the commonly used standard

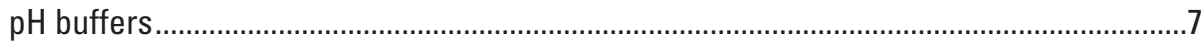

6.4-4. Troubleshooting guide for $\mathrm{pH}$ measurement .............................................................20 


\section{Conversion Factors}

U.S. customary units to International System of Units

\begin{tabular}{lll}
\hline \multicolumn{1}{c}{ Multiply } & \multicolumn{1}{c}{ By } & \multicolumn{1}{c}{ To obtain } \\
\hline gallon (gal) & 3.785 & liter $(\mathrm{L})$ \\
pound, avoirdupois $(\mathrm{lb})$ & 0.4536 & kilogram $(\mathrm{kg})$ \\
\hline
\end{tabular}

International System of Units to U.S. customary units

\begin{tabular}{lll}
\hline \multicolumn{1}{c}{ Multiply } & \multicolumn{1}{c}{ By } & \multicolumn{1}{c}{ To obtain } \\
\hline kilogram $(\mathrm{kg})$ & 2.205 & pound, avoirdupois $(\mathrm{lb})$ \\
liter $(\mathrm{L})$ & 0.2642 & gallon $(\mathrm{gal})$ \\
liter $(\mathrm{L})$ & 61.02 & cubic inch $\left(\mathrm{in}^{3}\right)$ \\
microgram $(\mu \mathrm{g})$ & $3.527 \times 10^{-8}$ & ounce, avoirdupois $(\mathrm{oz})$ \\
milligram $(\mathrm{mg})$ & $3.527 \times 10^{-5}$ & ounce, avoirdupois $(\mathrm{oz})$ \\
milliliter $(\mathrm{mL})$ & 0.0338 & ounce, fluid $(\mathrm{oz})$ \\
milliliter $(\mathrm{mL})$ & $2.642 \times 10^{-4}$ & gallon $(\mathrm{gal})$ \\
\hline
\end{tabular}

Temperature is reported in degrees Celsius $\left({ }^{\circ} \mathrm{C}\right)$, which can be converted to degrees Fahrenheit $\left({ }^{\circ} \mathrm{F}\right)$ by use of the following equation:

$$
{ }^{\circ} \mathrm{F}=1.8\left({ }^{\circ} \mathrm{C}\right)+32
$$

Specific conductance is reported in microsiemens per centimeter at 25 degrees Celsius ( $\mu \mathrm{S} / \mathrm{cm}$ at $\left.25^{\circ} \mathrm{C}\right)$.

\section{Abbreviations and Symbols}

\begin{tabular}{|c|c|}
\hline ANC & acid-neutralizing capacity \\
\hline ATC & automatic temperature compensation \\
\hline DIW & $\begin{array}{l}\text { deionized water with resistance greater than or equal to } 18 \text { megaohms }(\mathrm{M} \Omega) \text {, and } \\
\text { that has been quality assured }\end{array}$ \\
\hline e.m.f. & electromotive force \\
\hline HIF & Hydrologic Instrumentation Facility at Stennis Space Center, Mississippi (USGS) \\
\hline & ion-selective electrode \\
\hline $\mathrm{L}$ & liter \\
\hline & microgram per liter (equivalent to parts per billion [ppb]) \\
\hline $\mathrm{mg} / \mathrm{L}$ & milligram per liter (equivalent to parts per million [ppm]) \\
\hline M & molar \\
\hline $\mathrm{mV}$ & millivolts \\
\hline$\mu \mathrm{S} / \mathrm{cm}$ & microsiemens per centimeter (reported at $25^{\circ} \mathrm{C}$ ) \\
\hline FM & National Field Manual for the Collection of Water-Quality Data (USGS) \\
\hline $0 \mathrm{~A}$ & National Field Quality Assurance program (USGS) \\
\hline & National Field Supplies Service_-also referred to as "One-Stop Shopping" (USGS \\
\hline
\end{tabular}




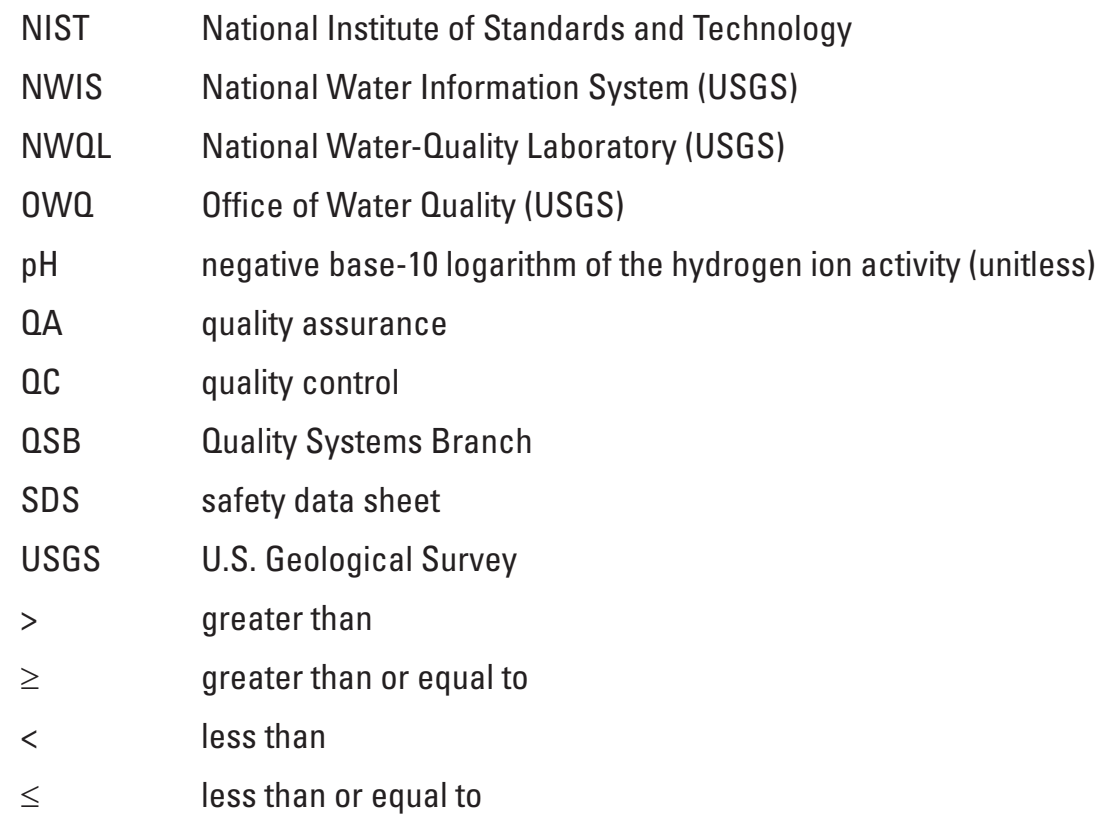

\section{Chemical Formulas}

$\begin{array}{ll}\mathrm{Ag} & \text { silver } \\ \mathrm{AgCl} & \text { silver chloride } \\ \mathrm{H}^{+} & \text {hydrogen ion } \\ \mathrm{HCl} & \text { hydrochloric acid } \\ \mathrm{H}_{2} \mathrm{O} & \text { water } \\ \mathrm{H}_{3} \mathrm{O}^{+} & \text {hydronium ion } \\ \mathrm{H}_{2} \mathrm{~S} / \mathrm{HS} & \text { hydrogen sulfide } \\ \mathrm{H}_{2} \mathrm{SO}_{4} & \text { sulfuric acid } \\ \mathrm{NaCl} & \text { sodium chloride } \\ \mathrm{NaOH} & \text { sodium hydroxide }\end{array}$




\section{Requirements and Recommendations}

As used in the U.S. Geological Survey (USGS) "National Field Manual for the Collection of Water-Quality Data" (NFM), the terms "required" and "recommended" have the USGSspecific meanings described below:

- The terms "require," "required," and "requirements" in reference to USGS protocols indicate that USGS Water Mission Area (WMA) policy has been established on the basis of research or consensus of the technical staff, and has been reviewed by waterquality specialists and other professionals having the appropriate expertise. Technical memorandums and other documents that define USGS WMA policy are cited in the NFM. USGS field personnel are instructed to use required equipment and procedures as described in the NFM. Departure from or modifications to stipulated requirements, if necessary for accomplishing specific data-quality requirements or study objectives, must be independently quality assured and documented (Office of Water Quality Technical Memorandum 2002.13-U.S. Geological Survey, 2002).

- The terms "recommend," "recommended," and "recommendation" indicate that, on the basis of research or consensus, there are several acceptable alternatives to a given procedure or equipment selection in the NFM. Relevant technical memorandums and publications pertinent to such recommendations are cited in the NFM to the extent that such documents are available. Specific requirements, data-quality objectives, or other constraints of a project may affect the choice of recommended equipment or procedures. Selection from among the recommended alternatives should be based on referenced research and sound field judgment, and reasons for the selection must be documented. Departures from or modifications to the recommended procedures must be independently quality assured and documented (Office of Water Quality Technical Memorandum 2002.13-U.S. Geological Survey, 2002). 


\title{
Chapter 6.4. Measurement of pH
}

\author{
By U.S. Geological Survey
}

\section{Abstract}

The "National Field Manual for the Collection of WaterQuality Data" (NFM) provides guidelines and procedures for U.S. Geological Survey (USGS) personnel who collect data used to assess the quality of the Nation's surface-water and groundwater resources. This chapter, NFM A6.4, provides guidance and protocols for the measurement of $\mathrm{pH}$ of a water sample, which include the scientific basis of the measurement, selection and maintenance of equipment, calibration, procedures for measurement and reporting, and troubleshooting. It updates and supersedes USGS Techniques of Water-Resources Investigations, book 9, chapter A6.4, version 2.0, by G.F. Ritz and J.A. Collins. The $\mathrm{pH}$ of natural waters is routinely measured when water samples are collected, is often measured continually at USGS streamgages, and is a parameter regularly measured during laboratory and field experiments. The field methods for measuring $\mathrm{pH}$ described in this chapter are applicable to most natural waters.

Before 2017, the NFM chapters were released in the USGS Techniques of Water-Resources Investigations series. Effective in 2018, new and revised NFM chapters are being released in the USGS Techniques and Methods series; this series change does not affect the content and format of the NFM. More information is in the general introduction to the NFM (USGS Techniques and Methods, book 9, chapter A0) at https://doi.org/tm9A0. The authoritative current versions of NFM chapters are available in the USGS Publications Warehouse at https://pubs.er.usgs.gov/. Comments, questions, and suggestions related to the NFM can be addressed tonfm@usgs.gov.

\subsection{Introduction}

The "National Field Manual for the Collection of WaterQuality Data" (NFM) is the official and citable protocol for the collection of water-quality data by the Water Mission Area (WMA) of the U.S. Geological Survey (USGS). The NFM provides guidelines and procedures for USGS personnel who collect data for water quality in surface water and groundwater, with detailed, comprehensive, and citable procedures. National USGS program and project personnel who collect water-quality data, as well as those in USGS water science centers and including those conducting projects supported by the USGS Cooperative program, are mandated to use protocols provided in the NFM (USGS Office of WaterQuality Technical Memorandum 2002.13-U.S. Geological Survey, 2002). Formal training, as provided in the USGS class "Field Water-Quality Methods for Groundwater and Surface Water," and field apprenticeships supplement the information provided in the NFM and are needed to collect unbiased, highquality data.

The USGS National Field Manual provides detailed, comprehensive, and citable procedures for monitoring the quality of surface water and groundwater. Formal training and field apprenticeships supplement the information provided in the NFM.

Chapter A6.4 provides guidance and protocols for the measurement of $\mathrm{pH}$ of a water sample, which include the scientific basis of the measurement, selection and maintenance of equipment, calibration, procedures for measurement and reporting, and troubleshooting. $\mathrm{pH}$ is an important variable in aquatic systems, and accurate measurements of this property are the basis for describing other attributes of those systems.

Before 2017, the NFM chapters were released in the USGS Techniques of Water-Resources Investigations series. Effective in 2018, new and revised NFM chapters are being released in the USGS Techniques and Methods series; this series change does not affect the content and format of the NFM. More information is in the general introduction to the NFM (USGS Techniques and Methods, book 9, chapter A0) at https://doi.org/tm9A0. The authoritative current versions of NFM chapters are available in the USGS Publications Warehouse at https://pubs.er.usgs.gov/. Comments, questions, and suggestions related to the NFM can be addressed to nfm@usgs.gov.

\subsection{Overview of $\mathrm{pH}$}

The $\mathrm{pH}$ of natural waters is routinely measured in the field as part of USGS studies of water quality. Many aquatic chemical processes, such as chemical speciation, solubility of minerals and gases, ion exchange on mineral surfaces, and the kinetics or rate of reactions, vary as a function of $\mathrm{pH}$. The 
$\mathrm{pH}$ of surface waters is affected diurnally by photosynthesis and respiration of algae and rooted macrophytes (Hem, 1989). Additionally, $\mathrm{pH}$ directly affects physiological functions of biota and is an important indicator of the health of an aquatic system.

The $\mathrm{pH}$ of water is defined as the negative base-10 logarithm of the hydrogen ion activity $\left\{\mathrm{H}^{+}\right\}$.

By definition,

$$
\begin{gathered}
\mathrm{pH}=-\log _{10}\left\{\mathrm{H}^{+}\right\} \text {, and } \\
\left\{\mathrm{H}^{+}\right\}=10^{-\mathrm{pH}} \text {, where } \\
\left\{\mathrm{H}^{+}\right\}=\text {activity of hydrogen ion. }
\end{gathered}
$$

\section{Information on $\mathrm{pH}-$}

- In aqueous solutions, the hydrogen ion $\left(\mathrm{H}^{+}\right)$exists as hydronium $\left(\mathrm{H}_{3} \mathrm{O}^{+}\right)$. For simplicity, " $\mathrm{H}^{+}$" is commonly used when defining $\mathrm{pH}$.

- Potentiometric measurements made by using ionselective electrodes (ISE) indicate free ionic activities rather than the actual concentrations of ions. Therefore, similar to other ion-selective electrodes (ISE), $\mathrm{pH}$ electrodes measure hydrogen ion activity.

- Activity can be thought of as an "effective" concentration and differs from true molar concentration because of ion-ion interactions. The hydrogen ion activity is defined as the molar concentration of hydrogen ions multiplied by an activity coefficient that takes into account the interaction of hydrogen ions with other chemical species in the solution. For dilute waters, activity values of ions are similar to their molar concentrations. For waters with high ionic strengthfor example, brackish water or seawater-activities can differ substantially from molar concentrations. The theoretical basis of activity and activity coefficients and their relation to ionic strength and ionic concentrations are described in detail in Hem (1989) and Benjamin (2015).
- Activity is dimensionless; therefore, $\mathrm{pH}$ values are unitless.

- Because $\mathrm{pH}$ is based on a logarithmic scale, a change of $1 \mathrm{pH}$ unit is a 10-fold change in the hydrogen ion activity.

- Temperature and dissolved gases affect the chemical equilibria of ionic activities in aqueous solutions, including that of $\mathrm{H}^{+}(\mathrm{Hem}, 1989)$. For example, the neutral $\mathrm{pH}$ of pure water at 25 degrees Celsius $\left({ }^{\circ} \mathrm{C}\right)$ is defined as 7.00 , but the value is 6.92 at $30{ }^{\circ} \mathrm{C}$ and 7.48 at $0{ }^{\circ} \mathrm{C}$. In addition, pure water in equilibrium with the atmosphere at $25^{\circ} \mathrm{C}$ has a $\mathrm{pH}$ of 5.7 because of the dissolution and dissociation of carbon dioxide $\left(\mathrm{CO}_{2}\right)$ from the atmosphere.

- For an in-depth discussion of $\mathrm{pH}$ theory, see Bates (1965).

- Figure 6.4-1 shows the $\mathrm{pH}$ range of several types of natural waters (modified from Nordstrom (1997) USGS Training Course: Geochemistry for Groundwater Systems). Most groundwaters in the United States have $\mathrm{pH}$ values generally ranging from 6.0 to 8.5 (Hem, 1989). Care must be taken when measuring the $\mathrm{pH}$ of groundwaters because the water may be supersaturated with $\mathrm{CO}_{2}$ before it reaches the land surface, and degassing can increase $\mathrm{pH}$.

- River waters not affected by contamination generally have a $\mathrm{pH}$ in the range of 6.5 to 8.5 and commonly exhibit diel fluctuations in $\mathrm{pH}$ as a result of photosynthesis, respiration, and temperature, causing variations in dissolved $\mathrm{CO}_{2}$ (Hem, 1989). Some extreme $\mathrm{pH}$ measurements of waters in the field include -3.6 for hyperacidic mine waters (Nordstrom and Alpers, 1999), and 12.5 for pore water ascending through serpentinite mud volcanoes in the Marian forearc (Mottl, 2009).

pH-A unitless measurement defined as the negative base-10 logarithm of the hydrogen ion activity 

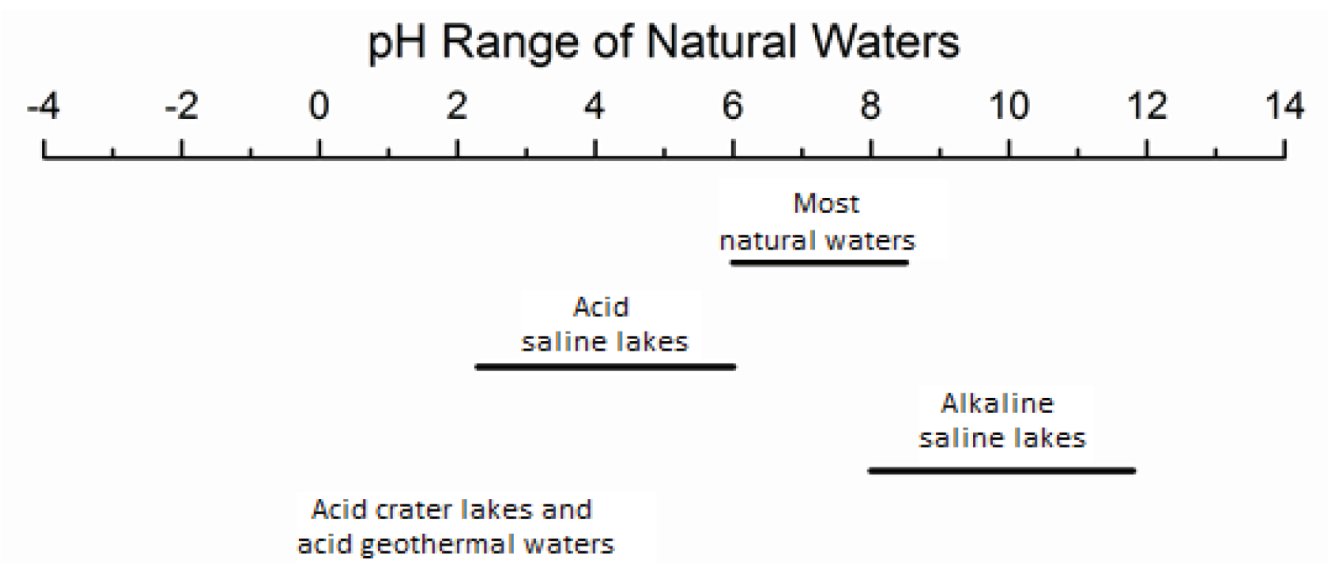

Alkaline geothermal waters and deep granitic groundwaters

\begin{abstract}
Acid rock drainage
Hyperacidic waters

(acid mine and volcanic waters)

Hyperalkaline waters (ultramafic rocks, serpentine, or calcium hydroxide groundwaters)
\end{abstract}

\subsection{Equipment and Supplies}

Modern instrumentation used to measure $\mathrm{pH}$ in environmental waters consists of a $\mathrm{pH}$ meter, a $\mathrm{pH}$ electrode, and a thermistor (table 6.4-1). The $\mathrm{pH}$ meter and electrode are calibrated by using standard $\mathrm{pH}$ buffers. Because a variety of $\mathrm{pH}$ meters and electrodes is available from manufacturers, the procedures described in this section may need to be modified depending on the specific instrumentation used, and the manufacturer's recommendations.

\section{Field personnel are required to-}

- Be familiar with the information provided in the manufacturer's user manual.

- Adhere to USGS protocols for measurement and quality assurance of $\mathrm{pH}$.

- Test the meter and electrode before each field trip by calibrating in the laboratory and recording calibration information in a $\mathrm{pH}$-meter/electrode logbook.

- Check the pH meter and electrode in the field and record the information in a $\mathrm{pH}$-meter/ electrode logbook.

- Ensure that $\mathrm{pH}$ buffers used for calibration are matched to the built-in automatic temperature compensation (ATC) in the calibration software of the meter, and that the buffers have not expired. safely.

\section{$2.1 \mathrm{pH}$ Meters}

Figure 6.4-1. Diagram showing typical $\mathrm{pH}$ range of natural waters. (Modified from Nordstrom, 1997)

- Record temperature with each measurement of $\mathrm{pH}$, because temperature affects the operation of $\mathrm{pH}$ meters, electrodes, and buffer solutions.

- Keep Chemical Safety Data Sheets (SDS) readily available and refer to them to ensure that $\mathrm{pH}$ buffers and other chemicals are handled safely.

Temperature affects the operation of $\mathrm{pH}$ meters, electrodes, and buffer solutions. CAUTION: Keep Chemical Safety Data Sheets (SDS) readily available and refer to them to ensure that $\mathrm{pH}$ buffers and other chemicals are handled

$\mathrm{A} \mathrm{pH}$ meter is a high-impedance voltmeter that measures the very small electrical potential (in millivolts $[\mathrm{mV}]$ ) generated between a glass bulb $\mathrm{pH}$ electrode and a $\mathrm{pH}$ reference electrode (fig. 6.4-2). Combination electrodes are used in most USGS field studies. They contain both a $\mathrm{pH}$ electrode and a reference electrode in one body and typically connect to the $\mathrm{pH}$ meter by using a multiple pin connector. Modern meters have a digital display and typically can display $\mathrm{pH}$, electromotive force (e.m.f.) in millivolts, and temperature in degrees Celsius $\left({ }^{\circ} \mathrm{C}\right)$. The potentiometric measurement is converted to a $\mathrm{pH}$ value either by interpolation or extrapolation with a standard calibration curve (interpolation is preferred). Meters 
Table 6.4-1. Equipment and supplies used for measuring pH.

[Modified from Ritz and Collins, 2008; mL, milliliters]

\begin{tabular}{|c|c|}
\hline$\checkmark$ & Checklist \\
\hline & $\begin{array}{l}\text { - } \mathrm{pH} \text { meter and pH electrodes } \\
\text { - } \mathrm{pH} \text { electrode filling solution of appropriate composition and molarity (for liquid-filled electrodes) } \\
\text { - } \mathrm{pH} \text { electrode storage solution } \\
\text { - } \text { Thermistor (or thermometer), calibrated } \\
\text { - Standard pH buffer solutions } 4,7 \text {, and } 10 \text {, labeled with expiration date (standard buffer solutions pH } 1.68 \text { or } 2 \text { are also needed if } \\
\text { acidic waters are measured); temperature correction chart(s) for buffers } \\
\text { - Stand for holding pH electrode or multiparameter instrument } \\
\text { - Bottle, delivery (squeeze), to dispense deionized water } \\
\text { - Deionized water } \\
\text { - Beakers or measurement vessels (preferably polyethylene or Teflon), assorted volumes of } 50 \text { to } 150 \text { mL, clean but not acid rinsed } \\
\text { - Flow-through chamber } \\
\text { - Bucket, cooler, or minnow bucket (or mesh bag) with tether, used for temperature equilibration of buffer solutions } \\
\text { - Waste-disposal container } \\
\text { - } \text { pH-meter/electrode logbook, either paper or digital, for recording calibrations, maintenance, and repairs } \\
\text { - Spare batteries and, if available, spare meter and electrode } \\
\text { - Safety Data Sheets for all pH buffers and other reagents to be used }\end{array}$ \\
\hline
\end{tabular}

obtained and used for $\mathrm{pH}$ measurements of groundwater or surface water or for use during alkalinity titrations are required to:

- Be battery powered, solid state, with ATC.

- Have a pH range of at least 2 to 12 , preferably 0 to 14 .

- Have an accuracy of at least $\pm 0.1 \mathrm{pH}$ units or greater with resolution of $0.01 \mathrm{pH}$ units.

- Have a temperature range of at least 0 to $+45^{\circ} \mathrm{C}$ (adequate for most surface and groundwaters).

- Have a millivolt readout with accuracy of $\pm 0.1 \mathrm{mV}$.

\section{$2.2 \mathrm{pH}$ Electrodes}

The $\mathrm{pH}$ electrode is a special type of ion-selective electrode (ISE) that is designed specifically for the measurement of $\mathrm{H}^{+}$activity in aqueous solution (fig. 6.4-2). Because $\mathrm{pH}$ measurements of natural waters are most commonly made with glass bulb electrodes, other types of $\mathrm{pH}$ electrodes are not discussed. Combination glass bulb electrodes are made in a variety of shapes and sizes by many manufacturers, but all operate on the same principles. Depending on use, the typical useful life expectancy of $\mathrm{pH}$ electrodes used in environmental field operation is approximately 12 to 18 months.

\subsubsection{How a Combination pH Electrode Works}

Combination glass bulb electrodes contain both a $\mathrm{pH}$ electrode and a reference electrode. The $\mathrm{pH}$ electrode generates an electrical potential that is proportional to the concentration of hydrogen ions in the sample solution, whereas the reference electrode generates a constant electrical potential. The electrodes together form a complete electrical circuit; when the diffusion of hydrogen ions across the glass bulb membrane reaches equilibrium, no electrical current is present, and the difference in electrical potential that exists between the reference and the $\mathrm{pH}$ electrodes is related to the hydrogen ion activity in the solution.

A glass bulb $\mathrm{pH}$ electrode has a thin porous glass membrane (bulb) that separates the solution being measured from the internal solution. When a $\mathrm{pH}$ electrode is immersed in a solution, hydrogen ions are exchanged with the sodium ions within the thin hydrated layer of the glass membrane until equilibrium between the internal and external solutions is 


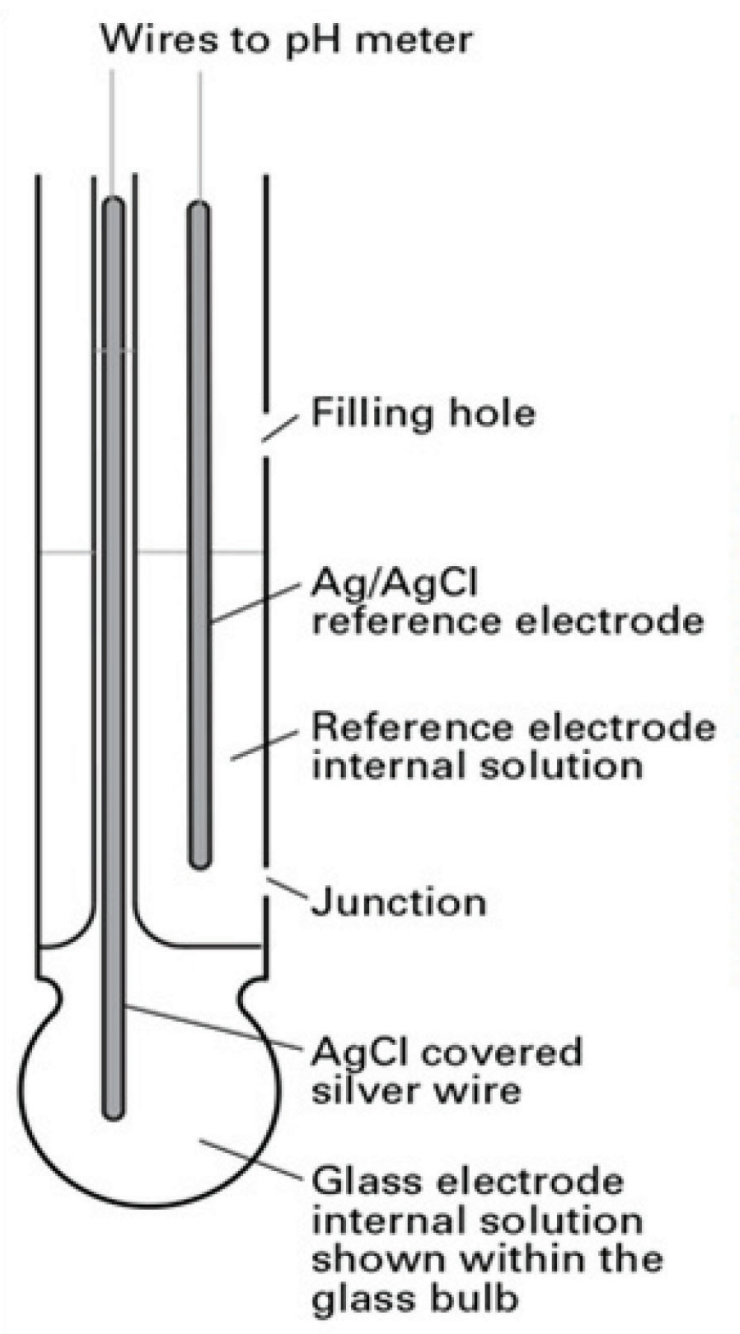

The active part of the electrode is the glass "membrane" or bulb. The body of the electrode whether glass or epoxy is thick walled, whereas the bulb is made to be as thin as possible. The surface of the glass bulb is protonated by both internal and external solutions until equilibrium is achieved. Both sides of the glass are charged by the adsorbed protons; this charge is responsible for a potential difference (described by the Nernst equation) and is directly proportional to the difference in $\mathrm{pH}$ between the solutions on both sides of the glass bulb.

Figure 6.4-2. Diagram of a combination (single-junction) pH electrode (Ag, silver; $\mathrm{AgCl}$, silver chloride). Modified from pH-meter.info$\mathrm{pH}$ electrode construction, accessed February 4, 2020, at http://www.ph-meter.info/pH-electrode-construction.

reached, resulting in a small electrical potential (measured in millivolts). The voltage potential across the glass membrane during sample measurement is $\mathrm{pH}$ dependent and is defined by the Nernst equation. The internal solution is typically a $\mathrm{pH}-7$ buffer solution and, therefore, most $\mathrm{pH}$ electrodes have an isopotential point (e.m.f. $=0 \mathrm{mV}$ ) at $\mathrm{pH} 7\left(\mathrm{pH}_{\text {iso }}\right)$.

The response of the $\mathrm{pH}$ electrode conforms to the Nernst equation, which is modified below:

$$
\mathrm{E}=\mathrm{E}_{0}+\mathrm{k} \cdot\left(\mathrm{pH}_{\text {iso }}-\mathrm{pH}\right)
$$

where $\mathrm{E}$ is the potential (in millivolts) of the solution being measured, $\mathrm{E}_{0}$ is the isopotential point (e.m.f. $=0 \mathrm{mV}$ ) for a $\mathrm{pH}-7$ solution $\left(\mathrm{pH}_{\mathrm{is}}\right)$, and $\mathrm{k}=59.16 \mathrm{mV}$ at $25^{\circ} \mathrm{C}=2.3 \mathrm{RT} / \mathrm{F}$, where $\mathrm{R}$ is the gas constant, $\mathrm{T}$ is the temperature, and $\mathrm{F}$ is Faraday's constant.

The reference electrode is not responsive to hydrogen ions, and therefore provides a constant reference potential against which the glass membrane potential can be measured.
Most manufacturers make reference electrodes using silver wire coated in silver chloride (silver-silver chloride); however, calomel (mercury-mercury chloride) and ROSS (platinumiodine/iodine) reference electrodes are commonly used. A liquid junction separates the filling solution in the reference electrode from the external solution being measured and completes the circuit (fig. 6.4-2).

The reference-electrode filling solution is an ionic solution that is the source of mobile ions that complete the electrical circuit between the reference and $\mathrm{pH}$-measurement electrodes. The reference electrode may be filled with either an ionic liquid solution (liquid-filled $\mathrm{pH}$ electrode) or an ionic gel solution (gel-filled $\mathrm{pH}$ electrode). Typically, these ionic solutions contain a chloride salt (commonly silver or potassium) of a known and specific concentration. For liquid-filled electrodes, maintaining a sufficient volume and the correct concentration of the filling solution, as recommended by the electrode manufacturer, within the electrode is required to obtain accurate measurements. 
The reference junction in the combination electrode is an electrically conductive bridge that completes the circuit between the reference solution and the sample being measured. Typically, this junction is made of a porous material such as ceramic, Teflon, or glass fiber. Glass capillary tubes are also used in some electrodes. A properly functioning junction is important for accurate $\mathrm{pH}$ measurements.

Combination electrodes are housed in either a glass or an epoxy body. Epoxy construction is recommended for field applications for durability. Most systems today (2020) include a thermistor for ATC. Depending on the $\mathrm{pH}$ meter, the thermistor may be a separate probe or may be built into the $\mathrm{pH}$ electrode, or, for multiparameter sondes, it may be incorporated into a different part of the instrument.
Electrode performance degrades with normal use and is required to be tracked in the $\mathrm{pH}$-meter/electrode logbook by changes in the calibration slope and isopotential point. Use of the electrode in severe chemical environments can cause more rapid deterioration (table 6.4-2). Many of these environments coincide with industrial and urban locations or waters that are highly acidic, have high concentrations of dissolved solids, or have high temperatures. If the $\mathrm{pH}$ electrode is exposed to conditions listed in table 6.4-2, this information should be recorded in the $\mathrm{pH}$-meter/electrode logbook and documented in field notes. Plan to replace the electrode more frequently if it will be used in the conditions listed in table 6.4-2. When measuring $\mathrm{pH}$ under specific adverse conditions, use electrodes that are designed to operate under those conditions (table 6.4-2).

Table 6.4-2. Recommended pH electrodes for a variety of water types.

[Modified from Ritz and Collins, 2008; $\mathrm{H}^{+}$, hydrogen ion; $\mathrm{Na}^{+}$, sodium ion; <, less than; >, greater than; $\geq$, greater than or equal to; ${ }^{\circ} \mathrm{C}$, degrees Celsius; DIW, deionized water; $\mathrm{M}$, molar; $\mu \mathrm{S} / \mathrm{cm}$, microsiemens per centimeter at $\left.25^{\circ} \mathrm{C}\right]$

\begin{tabular}{|c|c|c|c|}
\hline $\begin{array}{c}\text { Environmental or chemical } \\
\text { condition }\end{array}$ & Description of water & $\begin{array}{l}\text { Problem with a common } \\
\text { combination pH electrode }\end{array}$ & Recommended pH electrode \\
\hline Low ionic strength & $\begin{array}{l}\text { Specific conductance }<100 \mu \mathrm{S} / \\
\mathrm{cm}\end{array}$ & $\begin{array}{l}\text { Water is not sufficiently } \\
\text { conductive to complete the } \\
\text { electrical circuit, causing an } \\
\text { unstable pH reading. }\end{array}$ & $\begin{array}{l}\text { Fast-responding (liquid-filled) } \\
\text { electrode, Ross combination } \\
\text { glass electrode, double } \\
\text { junction electrode }\end{array}$ \\
\hline Low pH & Hyperacidic $(\mathrm{pH}<0)$ & $\begin{array}{l}\text { Contamination of the glass } \\
\text { electrode; non-Nernstian } \\
\text { response }\end{array}$ & Ross combination glass electrode \\
\hline Geothermal waters & $\begin{array}{l}\text { High temperature and elevated } \\
\text { silica concentration }\end{array}$ & $\begin{array}{l}\text { Polymerization and precipita- } \\
\text { tion of silica in the reference } \\
\text { junction upon probe cooling }\end{array}$ & $\begin{array}{l}\text { Ross combination glass elec- } \\
\text { trode (soak in } 80^{\circ} \mathrm{C} \text { DIW for } \\
30 \text { minutes after use) }\end{array}$ \\
\hline Acid-mine waters & $\begin{array}{l}\text { Low } \mathrm{pH} \text { and elevated iron } \\
\text { concentration }\end{array}$ & $\begin{array}{l}\text { Precipitation of iron and } \\
\text { aluminum hydroxides in the } \\
\text { reference junction }\end{array}$ & $\begin{array}{l}\text { Glass } \mathrm{pH} \text { electrode (soak in } \\
\text { dilute hydrochloric acid } \\
{[0.1 \mathrm{M}] \text { after use) }}\end{array}$ \\
\hline \multirow[t]{2}{*}{ Basic ions dominant in solution } & $\begin{array}{l}\text { High } \mathrm{pH}(>10) \text {; low } \mathrm{H}^{+} \text {activity } \\
\text { results in measurement of } \\
\text { other monovalent ions in } \\
\text { solution }\end{array}$ & $\begin{array}{l}\text { Sluggish response to changes in } \\
\mathrm{pH} \text {, resulting from dehydration } \\
\text { of the glass bulb membrane }\end{array}$ & $\begin{array}{c}\text { Glass } \mathrm{pH} \text { electrode designed for } \\
\text { measuring high values of } \mathrm{pH}\end{array}$ \\
\hline & $\begin{array}{l}\text { Elevated } \mathrm{Na}^{+} \text {activity at } \\
\mathrm{pH}>11.0 ; \mathrm{H}^{+} \text {activity is } \\
\text { low. The electrode senses } \\
\mathrm{Na}^{+} \text {activity as if it were } \mathrm{H}^{+} \\
\text {activity because of the similar- } \\
\text { ity of } \mathrm{Na}^{+} \text {and } \mathrm{H}^{+} \text {ions. }\end{array}$ & $\begin{array}{l}\text { The } \mathrm{pH} \text { measurement is } \\
\text { negatively biased. }\end{array}$ & $\begin{array}{c}\text { Glass } \mathrm{pH} \text { electrode designed for } \\
\text { measuring high values of } \mathrm{pH}\end{array}$ \\
\hline $\begin{array}{l}\text { Elevated concentration of sulfide } \\
\text { or cyanide }\end{array}$ & $\begin{array}{l}\text { Elevated concentrations of sul- } \\
\text { fide or cyanide are found in in- } \\
\text { dustrial, mined, or urban areas. }\end{array}$ & $\begin{array}{l}\text { Sulfide or cyanide contamination } \\
\text { of the reference electrode }\end{array}$ & $\begin{array}{l}\text { Double-junction electrodes, } \\
\text { plasticized reference } \\
\text { electrodes }\end{array}$ \\
\hline $\begin{array}{l}\text { Elevated concentration of ferric } \\
\text { chloride }\end{array}$ & $\begin{array}{l}\text { Ferric chloride is used as a } \\
\text { flocculating agent in waste- } \\
\text { water-treatment plants, for } \\
\text { example. }\end{array}$ & $\begin{array}{l}\text { Ferric chloride affects the glass } \\
\text { bulb membrane of the } \mathrm{pH} \\
\text { electrode, deactivating many } \\
\text { of the sensing sites on the } \\
\text { glass surface. }\end{array}$ & $\begin{array}{l}\text { Consult the manufacturer for } \\
\text { information on (1) selecting } \\
\text { pH electrodes that can } \\
\text { withstand this environment; } \\
\text { and (or) (2) specific cleaning } \\
\text { procedures for the glass bulb } \\
\text { membrane. }\end{array}$ \\
\hline
\end{tabular}




\subsection{Standard pH Buffer Solutions}

Standard $\mathrm{pH}$ buffer solutions (buffers) are ionic solutions that are used to calibrate the $\mathrm{pH}$ meter and electrodes. Buffers maintain constant $\mathrm{pH}$ values (at a single temperature) because of their ability to resist changes to the specific $\mathrm{pH}$ value for which they are produced. However, the $\mathrm{pH}$ of solutions is affected by temperature, because the calibration slope (which is related to the Nernst equation) and the isopotential point change with temperature. Modern $\mathrm{pH}$ meters are typically calibrated with $\mathrm{pH}$ buffers having well-known $\mathrm{pH}$-temperature correlations; quality-assured and National Institute of Standards and Technology- (NIST) traceable $\mathrm{pH}$ buffers are available from USGS One-Stop ${ }^{1}$. Most $\mathrm{pH}$ meters recognize the e.m.f. range of certain $\mathrm{pH}$ buffers (commonly $\mathrm{pH} 1.68$, $4.01,7.00$, and 10.01 buffers) and are able to automatically compensate for temperature during calibration. Verify that the buffers you are using are NIST-traceable, that the values are recognized correctly by the meter, and that the buffers are compatible with the ATC for your meter. Consult the manufacturer's manual to be sure that the meter will adjust the expected value of the buffer for the temperature measured. The user may be responsible for entering the temperature-adjusted buffer $\mathrm{pH}$ value into the meter for calibration from a chart or the meter may automatically generate a temperature-adjusted $\mathrm{pH}$ value for the buffer.

Measurements of pH are only as accurate as the buffers used to calibrate the meter and electrodes.

The commonly used $\mathrm{pH}$ buffer solutions and their corresponding $\mathrm{pH}$ values from 0 to $90^{\circ} \mathrm{C}$ are shown in table 6.4-3. The $\mathrm{pH}$ buffers $1.68,4.01$, and 10.01 are primary standards ( $\mathrm{pH}$ values determined by using the standard hydrogen-gas electrode). Their compositions are typically similar for various manufacturers; therefore, their variations in $\mathrm{pH}$ with temperature are well known. The $\mathrm{pH}-7.00$ buffer is a secondary standard ( $\mathrm{pH}$ values determined by interpolation to primary standards) and its composition (and therefore $\mathrm{pH}$ dependence on temperature) may differ with the manufacturer. However, the $\mathrm{pH}-7.00$ buffer is typically made either from potassium dihydrogen phosphate plus sodium hydroxide or from potassium dihydrogen phosphate plus sodium hydrogen phosphate; the $\mathrm{pH}$ values of both buffer formulations are comparable to within $0.02 \mathrm{pH}$ units from 0 to $90^{\circ} \mathrm{C}$.

Use the following precautions and protocols to ensure the accuracy of the $\mathbf{~ p H}$ buffers - (modified from Busenberg and Plummer, 1987):

\footnotetext{
${ }^{1}$ Equipment and supplies that are tested and quality assured are available to USGS field studies from the National Field Supply Service (NFSS) and the Hydrologic Instrumentation Facility (HIF), and are sold through the USGS One Stop ordering system (accessed February 5, 2020, at https://1stop.usgs.gov/) (internal USGS access only).
}

- Use only buffers that have been certified traceable to a NIST standard reference material.

- Label pH buffer containers with the date opened and the expiration date. Copy the expiration date and the buffer lot number onto any reagent containers into which the buffer is transferred. This information is also recorded in the $\mathrm{pH}$-meter/electrode logbook.

- Do not use expired buffers.

- Cap buffer bottles firmly after use to prevent evaporation and contamination.

- Never pour used buffer back into a bottle containing the stock buffer solution.

Table 6.4-3. Values of $\mathrm{pH}$ from 0 to 90 degrees Celsius $\left({ }^{\circ} \mathrm{C}\right)$ for the commonly used standard $\mathrm{pH}$ buffers.

[Values from Buck and others, 2002; and Robinson and Stokes, 1965]

\begin{tabular}{ccccc}
\hline \multirow{2}{*}{$\begin{array}{c}\text { Temperature } \\
\text { in }{ }^{\circ} \mathbf{C}\end{array}$} & \multicolumn{4}{c}{$\mathbf{p H}$ buffer at $\mathbf{2 5}^{\circ} \mathbf{C}$} \\
\cline { 2 - 5 } & $\mathbf{1 . 6 8} \mathbf{1}^{\mathbf{0}}$ & $\mathbf{4 . 0 1 ^ { 2 }}$ & $\mathbf{7 . 0 0 ^ { 3 }}$ & $\mathbf{1 0 . 0 1 ^ { 4 }}$ \\
\hline 0 & 1.67 & 4.00 & 7.12 & 10.32 \\
5 & 1.67 & 4.00 & 7.09 & 10.25 \\
10 & 1.67 & 4.00 & 7.06 & 10.18 \\
15 & 1.67 & 4.00 & 7.04 & 10.12 \\
20 & 1.68 & 4.00 & 7.02 & 10.06 \\
25 & 1.68 & 4.01 & 7.00 & 10.01 \\
30 & 1.68 & 4.01 & 6.99 & 9.97 \\
35 & 1.69 & 4.02 & 6.98 & 9.93 \\
40 & 1.69 & 4.03 & 6.97 & 9.89 \\
45 & 1.70 & 4.04 & 6.97 & 9.86 \\
50 & 1.71 & 4.05 & 6.97 & 9.83 \\
55 & 1.71 & 4.06 & 6.97 & 9.80 \\
60 & 1.72 & 4.08 & 6.98 & 9.78 \\
65 & 1.73 & 4.10 & 6.99 & 9.77 \\
70 & 1.74 & 4.12 & 7.00 & 9.75 \\
75 & 1.75 & 4.14 & 7.02 & 9.74 \\
80 & 1.76 & 4.16 & 7.04 & 9.73 \\
85 & 1.78 & 4.18 & 7.06 & 9.73 \\
90 & 1.79 & 4.21 & 7.09 & 9.72 \\
\hline
\end{tabular}

${ }^{1} \mathrm{pH} 1.68$ buffer: 0.05 mole per kilogram $(\mathrm{mol} / \mathrm{kg})$ potassium tetroxalate ${ }^{2} \mathrm{pH} 4.01$ buffer: $0.05 \mathrm{~mol} / \mathrm{kg}$ potassium biphthalate

${ }^{3} \mathrm{pH} 7.00$ buffer: $0.063 \mathrm{~mol} / \mathrm{kg}$ potassium dihydrogen phosphate and 0.037 $\mathrm{mol} / \mathrm{kg}$ sodium hydroxide

${ }^{4} \mathrm{pH} 10.01$ buffer: $0.025 \mathrm{~mol} / \mathrm{kg}$ sodium bicarbonate and $0.025 \mathrm{~mol} / \mathrm{kg}$ sodium carbonate 
- Do not insert an electrode or other material into a bottle containing stock buffer solution-always pour the buffer into a separate container and discard the solution after use.

- Do not contaminate the buffer or sample by placing a wet or contaminated electrode into the solution to be measured (this can happen, for example, if drops of deionized water (DIW) used to clean the electrode drip into the buffer or if buffer solution drips into the sample). To minimize contamination or dilution, rinse the electrode with the solution to be measured by slowly pouring the sample or buffer to be measured over the electrode. Then place the electrode into the vessel containing the sample or buffer, remove the electrode, and dispose of the sample or buffer. Repeat this procedure for a total of three times every time a measurement is made. To measure the sample $\mathrm{pH}$, add fresh sample or buffer to the same vessel and then place the electrode directly into the measurement vessel. This procedure ensures that the $\mathrm{pH}$ electrode and measurement vessel are well rinsed prior to measurement.

- Protect buffers against wide temperature variations, whether they are in transit, in use, or in storage. Never expose buffers to extreme heat or freezing temperatures. If buffers experience these conditions, their $\mathrm{pH}$ values can no longer be assumed to be valid and they should be discarded appropriately.

\subsection{Maintenance and Preparation of pH Instruments}

Proper care of $\mathrm{pH}$ meters, and particularly of the electrode, is essential for maintaining the accuracy and precision required for $\mathrm{pH}$ measurements and increases the longevity of the equipment. Maintenance includes adhering to the manufacturer's instructions for the use and care of the $\mathrm{pH}$ instrument system, routine electrode cleaning, reconditioning, and storage requirements. As always, follow the manufacturer's instructions for the specific type of electrode in use.

pH-meter and electrode performance is required to be checked before each water-quality field trip and at each field site.

\subsection{Electrode Care and Cleaning}

USGS field personnel should integrate the following guidance for the care and cleaning of $\mathrm{pH}$ electrodes into their routine field-measurement procedures.
- Never handle the glass bulb with bare fingers. Oily film or scratches on the bulb will interfere with the design characteristics of the glass bulb membrane and affect $\mathrm{pH}$ measurements.

- Inspect the electrode and electrode cable for:

- cut or frayed cable(s)

- broken connectors and mismatched or missing parts

- a visibly scratched or broken glass bulb, cracked electrode body, and broken or damaged internal electrodes (reference and measurement electrodes)

- a visibly contaminated reference junction

- low filling solution

- Periodically remove and replace the filling solution

- Gel-filled electrodes do not require filling and typically require less maintenance than liquid-filled electrodes.

- Do not store gel-filled electrodes in low-ionicstrength water, including DIW, even temporarily, as ions will leach from the gel into the dilute water, causing dilution of the filling gel and errors in $\mathrm{pH}$ measurements. There is no easy way to recondition or replace the ionic gel.

- Do not store $\mathrm{pH}$ meters and electrodes in extreme heat or cold.

A clean, undamaged glass bulb membrane is necessary for obtaining an accurate measurement of pH. Avoid touching or scratching the glass bulb membrane, and check it regularly for scratches.

To prepare $\mathrm{pH}$ electrodes for use:

- If the electrode is refillable, check the filling-solution level and replenish the solution if necessary. The solution should reach the bottom of the fill hole. Gently swirl the electrode and allow a few minutes after adding solution for equilibration. Filling solutions differ in concentration and composition-always check that the correct filling solution required by the manufacturer for a particular electrode is being used.

- Drain and flush the reference chamber of refillable electrodes, and routinely refill them with the correct filling solution (check the manufacturer's recommendations). Allow the probe to re-equilibrate before calibration. 
- Record in the $\mathrm{pH}$-meter/electrode logbook the operational history, including calibration slope, isopotential point, and conditions of use, of each $\mathrm{pH}$ electrode identified by serial number.

- Record the calibration slope, isopotential point, temperature readings, and millivolt readings of the $\mathrm{pH}$ buffers during calibration. Properly working electrodes should yield 95 to 101 percent (56.2 to $59.8 \mathrm{mV} / \mathrm{pH}$ unit at $25^{\circ} \mathrm{C}$ ) of the response expected according to the theoretical Nernst equation (Busenberg and Plummer, 1987).

- When measuring $\mathrm{pH}$ buffers, note whether stabilization of the electrode requires more than 2 to 3 minutes. Slow response times may indicate reduced electrode performance or a clogged reference junction.

\section{For routine cleaning of the $\mathrm{pH}$ electrode:}

Electrodes must be kept clean and the reference junction must be flowing freely to obtain accurate $\mathrm{pH}$ measurements. Because a variety of electrodes is available, check the manufacturer's instructions for specific tips and precautions.

- Before and after each use, rinse the electrode body thoroughly, using only DIW.

- Do not wipe or wick moisture from electrodes with paper towels or other paper-based wipes, as they can scratch the glass bulb membrane. Wiping the electrode body with paper also may cause a static charge (polarization) on the exterior of the $\mathrm{pH}$ electrode, which likewise can adversely affect the $\mathrm{pH}$ measurement. Gently shaking electrodes to remove drops of liquid is recommended. To prepare an electrode for measurement, rinse it with the solution to be measured by slowly pouring a small amount of the sample or buffer to be measured over the electrode. Then place the electrode into the vessel containing the sample or buffer, remove the electrode, and dispose of the sample or buffer. Repeat this process for a total of three times prior to each $\mathrm{pH}$ measurement. To measure the $\mathrm{pH}$ of the sample, add fresh sample or buffer to the same vessel and then place the electrode directly into the measurement vessel.

- If using a liquid-filled electrode that has been in a storage solution for a long time (typically weeks to months), uncap the fill hole and suspend the electrode in the air for about 15 minutes. This procedure will allow the filling solution to flush residual storage solution through the porous reference junction and thoroughly wet the junction.

- Soak the electrode (whether gel- or liquid-filled) in $0.1-\mathrm{M} \mathrm{HCl}$ for 30 minutes. This procedure removes many of the solid precipitates that may be fouling the reference junction. Thoroughly rinse the electrode with DIW before using or storing.

- If the electrode is contaminated with oil or grease, soak it in 0.5-percent mild liquid dishwashing detergent solution for 3 minutes. Thoroughly rinse the electrode with DIW before using or storing.

- For cleaning bacterial contaminants, soak the electrode in a dilute (1:10 volume per volume) solution of bleach (sodium hypochlorite) for 30 minutes. Thoroughly rinse the electrode with DIW before using or storing.

\subsection{Reconditioning (Flushing and Refilling) of Liquid-Filled Electrodes}

If problems persist during calibration of a liquid-filled electrode, or if there is reason to doubt that the electrode is in good working condition, check the manufacturer's instructions for testing and reconditioning the electrode. Reconditioning procedures should be implemented if the electrode's slope response has deteriorated to less than 95 percent or greater than 101 percent, if the meter no longer recognizes the $\mathrm{pH}$ buffers because of shifting of the isopotential point, or if the response time is longer than expected. Document the date, serial number, and action in the $\mathrm{pH}$-meter/electrode logbook if the electrode has been reconditioned or replaced. Salt crystal deposits in the reference electrode or reference junction commonly cause $\mathrm{pH}$ electrodes to malfunction. The following general procedure for renewing the filling solution can be used to attempt to bring a liquid-filled electrode back into proper working condition. If the electrode has a replaceable reference junction, follow the manufacturer's instructions for changing the reference junction, which may require renewing the filling solution. If the electrode does not have a replaceable reference junction, follow the general instructions below to renew the filling solution.

1. Remove the old filling solution from the electrode.

- Use a small pipet or syringe to remove the filling solution through the filling hole. Another method of removing the filling solution is to wick it out with a laboratory wipe. The electrode manufacturer also may have specific recommendations for removing the filling solution.

2. Flush the $\mathrm{pH}$ electrode with DIW.

- Use a pipet, syringe, or squeeze bottle to partially fill the $\mathrm{pH}$ electrode chamber with DIW.

- Remove the DIW from the electrode as described above. 
- As a result of changes in pressure, temperature, or evaporation of the filling solution, visible crystals may have formed in the $\mathrm{pH}$ electrode. If these are present, continue to flush with DIW until all the crystals have been dissolved and removed from the $\mathrm{pH}$ electrode.

- Do not leave DIW in the reference electrode after cleaning.

3. Flush and fill the electrode with fresh filling solution by using a syringe or equipment recommended by the manufacturer.

- Partially fill the $\mathrm{pH}$ electrode chamber with the filling solution.

- Tilt the $\mathrm{pH}$ electrode so the filling solution will contact all of the internal electrode surfaces.

- Remove and discard the filling solution to a waste container and repeat the two steps above.

- Refill the electrode chamber with fresh filling solution until the filling-solution level is just below the fill hole.

\section{- Be sure to use the appropriate type and} concentration of filling solution.

- Rinse any excess filling solution from the outside of the electrode with DIW.

4. Test the electrode by performing a calibration and recording the slope and isopotential point. The slope should be in the range of 95 to 101 percent (56.2 to $59.8 \mathrm{mV} / \mathrm{pH}$ unit at $25^{\circ} \mathrm{C}$ ) of the response expected according to the theoretical Nernst equation. If the slope falls outside this range, do not use the electrode.

\subsection{Electrode Storage}

Electrodes must be clean before they are stored for any length of time. Refer to the manufacturer's instructions for the proper short-term (used daily or weekly) and long-term (months) storage requirements of the electrode.

\section{General guidelines for short-term storage:}

- Storage solutions are specific to the type of electrode; check the manufacturer's manual for each electrode.

Do not store pH electrodes in DIW unless instructed to do so by the manufacturer.

- Storage solutions have a limited shelf life. Label storage-solution containers with the expiration date and discard expired solutions in an appropriate manner.
- Do not place cotton or paper towel in the electrode cap to help keep it moist, as this practice can scratch the glass bulb membrane.

- Store $\mathrm{pH}$ electrodes upright so the filling solution or gel is always in contact with the reference junction.

- Store $\mathrm{pH}$ electrodes wet between uses to maximize their accuracy and response time.

- The glass bulb membrane should be fully immersed in the proper electrode-storage solution.

- For liquid-filled electrodes, replace the plug on the fill hole and cover the electrode bulb with the cap between uses. Fill the cap with enough storage solution to keep the bulb wet.

- Storing the electrode in either $\mathrm{pH}-4$ or -7 buffer may be recommended for short-term storage (less than 1 day). Unless it is recommended by the manufacturer, do not store the electrode in buffer solution for a long period.

- Gel-filled electrodes should be stored according to the manufacturer's instructions.

\section{General guidelines for long-term storage:}

- Store electrodes in the appropriate storage solution and cap as recommended by the manufacturer. For long-term storage, wrap the electrode cap and filling-hole plug with lab plastic wrap (Parafilm) to prevent formation of excess salts or evaporation of the reference solution. Liquid-filled electrodes may need to be drained of filling solution; follow the manufacturer's instructions.

- Clean the electrode cable contacts and connector (with alcohol, if necessary). Allow the contacts to dry thoroughly, and seal and store them in a plastic bag.

- Store every component of the pH-measuring system in an area that is clean, dry, and protected from extreme hot or cold temperatures.

\subsection{Calibration of the $\mathrm{pH}$ Instrument System}

Proper calibration of the $\mathrm{pH}$ instrument system is crucial to accurate measurement of the $\mathrm{pH}$ of environmental samples. A calibration curve is created by measurement of two or more standard $\mathrm{pH}$ buffers that bracket the $\mathrm{pH}$ of the water being measured. The ideal slope of the calibration curve at $25^{\circ} \mathrm{C}$, based on the Nernst equation (see section 2.2), is $59.16 \mathrm{mV} / \mathrm{pH}$ unit. Almost all $\mathrm{pH}$ electrodes are designed to 
have an isopotential point at $\mathrm{pH} 7$ (the $\mathrm{pH}$ at which e.m.f. is equal to $0 \mathrm{mV}$ ). Most modern $\mathrm{pH}$ meters are equipped with ATC, which compensates for the temperature dependence of the standard buffers. The Nernst equation gives the expected (theoretical) response potential of the $\mathrm{pH}$ buffer at the specific temperature of the calibration (Hem, 1989), and after calibration most meters report the calibration slope as a percentage of the Nernstian theoretical slope. To successfully calibrate $\mathrm{pH}$ instrumentation, (1) the meter and $\mathrm{pH}$ electrode must be functioning properly, (2) the system must be calibrated with $\mathrm{pH}$ buffers so the $\mathrm{pH}$ of the solution being measured is within the calibrated range, and (3) the temperature of the $\mathrm{pH}$ buffers during calibration needs be stable and similar to (within $10^{\circ} \mathrm{C}$ of) the temperature of the solution being measured.

\section{A properly working $\mathrm{pH}$ system has-}

- new or adequately charged batteries

- a thermistor that functions properly and accurately measures the temperature

- a pH electrode with an accurate Nernstian response (slope of 95-101 percent of the theoretical Nernstian slope)

- an isopotential point near $\mathrm{pH} 7$

- a quick response time (1-2 minutes) in standard buffer solutions.

Accurate measurement of the $\mathrm{pH}$ of environmental samples requires calibration with $\mathrm{pH}$ buffers that bracket the $\mathrm{pH}$ of the sample. Before the $\mathrm{pH}$ instrument system is calibrated, it is useful to estimate (or anticipate from historical site data, if available) the $\mathrm{pH}$ and conductivity of the waters to be encountered at the field sites. If no data are available from which to estimate sample $\mathrm{pH}$, then $\mathrm{pH}$ indicator paper can be used onsite as a gross indicator of the $\mathrm{pH}$ of the site, but under no circumstances should a $\mathbf{p H}$ value from indicator paper be recorded as the site $\mathbf{p H}$. A two- or three-point calibration can be performed. Most manufacturers use a linear calibration curve for all calibrations (including multipoint calibrations). For most modern meters, a two-point calibration, typically with buffers selected from $\mathrm{pH} 10.01,7.00,4.01$, or 1.68 , is recommended. $\mathrm{pH}$ meters that use either a point-topoint calibration or a nonlinear function are not recommended. Follow the manufacturer's instructions with respect to recommended buffers and the sequence of buffer calibration.

\section{Examples: When measuring $\mathrm{pH}$ in a stream-}

- If $\mathrm{pH}$ values are expected to be between 7 and 8 , then the standard $\mathrm{pH}-7$ and $\mathrm{pH}-10.01$ buffers (at a minimum) should be selected.

- If $\mathrm{pH}$ values are expected to be less than 7, then the standard $\mathrm{pH}-7$ and $\mathrm{pH}-4.01$ buffers (at a minimum) should be selected.
For the two examples above, a three-point calibration using $\mathrm{pH}-4.01,-7.00$, and -10.01 buffers could also be used to allow measurement of a larger range of $\mathrm{pH}$.

The $\mathrm{pH}$ of a solution changes with temperature, and most modern $\mathrm{pH}$ meters automatically compensate for temperature differences between the buffers used for calibration and the measurements made in samples. However, electrodes may not behave ideally and this feature should be tested regularly. Calibrating a $\mathrm{pH}$ meter and electrode with buffers that are within $\pm 10{ }^{\circ} \mathrm{C}$ of the sample temperature is recommended. This task can be accomplished by placing the buffers in a mesh bag and equilibrating them to the temperature of the water at the sampling location before calibration. However, for most sampling situations, where the temperature of the water is between 5 and $35^{\circ} \mathrm{C}$ and the $\mathrm{pH}$ is between 4.0 and 9.5 , the recommended procedure is to calibrate the meter in the more controlled environment of the office laboratory, and then allow the meter to compensate for temperature differences at the sampling site. Again, the accuracy of field measurements should be checked regularly with buffers equilibrated to the environmentalsample temperatures to verify the readings. If the $\mathrm{pH}$ of the buffers checked at the field site at $\pm 10{ }^{\circ} \mathrm{C}$ of the temperature of the environmental sample is more than $\pm 0.05 \mathrm{pH}$ unit different from the value the buffer should return at that temperature, the meter and electrode should be recalibrated at a temperature that is $\pm 10^{\circ} \mathrm{C}$ of the field-measurement temperature.

For multiparameter sondes that will be deployed for continuous measurements in the field in a range of conditions, the recommended procedure is to calibrate in the laboratory and then conduct checks in the field at ambient temperatures to verify the accuracy of the readings. Recalibration may be necessary if the initial check is more than $\pm 0.05 \mathrm{pH}$ unit different from the value the buffer should return. If the measurement temperature is more than $\pm 10^{\circ} \mathrm{C}$ different from the laboratory calibration temperature, checks in the field are more likely to fail and recalibration may be necessary.

The following guidelines and standard procedures generally apply whenever a $\mathrm{pH}$ instrument system is to be calibrated. Because calibration and operating procedures can differ with the instrument system, check the manufacturer's recommended calibration procedures and calibration buffer solution requirements. Modern $\mathrm{pH}$ meters typically compensate for buffer temperatures automatically during calibration. When using these instruments, follow the manufacturer's calibration instructions and the more general instructions in the following procedures - do not take shortcuts.

- Before each field trip and site visit, check pH-meter/ electrode logbook records for electrode performance. Remember - any noted calibration slope of less than 95 percent or greater than 101 percent indicates probable electrode deterioration. If the slope is outside the acceptable range (95-101 percent), the electrode should be cleaned, reconditioned, or replaced, and the new electrode calibrated. If a liquid-filled electrode is being used, try reconditioning it (section 3.2) in the laboratory before replacing it with a new electrode. 
- Use at least two $\mathrm{pH}$ buffer solutions with documented, NIST-traceable $\mathrm{pH}$ values that bracket the sample $\mathrm{pH}$ for accurate calibration of the $\mathrm{pH}$ instrument system.

- If a large primary source of $\mathrm{pH}$ buffer is purchased initially, use a secondary bottle to store $\mathrm{pH}$ buffers while in the field to minimize the chance of contaminating the main $\mathrm{pH}$ buffer source. Pour the amount of each buffer needed from the source container into a clean polyethylene bottle dedicated for the respective buffer, and label the bottle with the buffer's $\mathrm{pH}$ value, lot number, and expiration date. Keep a printed chart of the temperature-adjusted $\mathrm{pH}$ values provided by the manufacturer for that buffer.

- A calibration check of the $\mathrm{pH}$ meter's temperature sensor is required to be performed at least annually (NFM A6.1). Most single-analyte $\mathrm{pH}$ meters use a thermistor built into the electrode. Multiparameter instruments typically have the temperature sensor in a different part of the instrument system than the $\mathrm{pH}$ electrode.

- The pH instrumentation should be calibrated daily and recalibrated if a check of either of the two $\mathrm{pH}$ buffers nearest to the $\mathrm{pH}$ of the sample at a temperature that is $\pm 10^{\circ} \mathrm{C}$ of the sample deviates by more than $\pm 0.05 \mathrm{pH}$ units.

- The isopotential point is the characteristic $\mathrm{pH}$ where the e.m.f. is equal to $0 \mathrm{mV}$. Most modern $\mathrm{pH}$ electrodes are designed to have an isopotential point at or near $\mathrm{pH}=7$. Test the electrode when it is new by placing it in $\mathrm{pH}-7.00$ buffer and record the voltage. Repeat this test regularly and verify that the value is $\pm 15 \mathrm{mV}$ of the original value. If the isopotential point is more than $\pm 15 \mathrm{mV}$ of the original value, clean, recondition, or replace the electrode.

Do not use $\mathrm{pH}$ buffers that have exceeded their date of expiration. Buffers that have been transferred to a secondary bottle for use while in the field should be refreshed before every field trip.

\subsection{Calibration Procedure}

The following calibration procedure is expected to yield accurate sample-pH measurements for waters with specific conductance less than $60,000 \mu \mathrm{S} / \mathrm{cm}$, temperatures from 0 to $90^{\circ} \mathrm{C}$, and $\mathrm{pH}$ in the range from 1.68 to 10 . Standard buffer solutions and combination $\mathrm{pH}$ electrode can be appropriately used to achieve an accurate measurement of the $\mathrm{pH}$ of environmental waters that is within these environmental ranges. Studies of waters with conditions that fall outside the ranges described above may require $\mathrm{pH}$ calibration and measurement modifications.

\subsubsection{Calibration of a Single-Parameter Meter and $\mathrm{pH}$ Electrode used for Sample Measurement or an Alkalinity Titration}

1. Under most situations, it is recommended to calibrate the $\mathrm{pH}$ meter and electrode in a controlled environment such as a laboratory rather than in the field. Most modern meters automatically adjust $\mathrm{pH}$ measurements for changes in temperature, and these corrections are usually accurate within a temperature range of 5 to $35^{\circ} \mathrm{C}$ and for $\mathrm{pH}$ measurements between 4.0 and 9.5. Electrodes may not behave ideally, however, and this feature should be tested regularly with measurements on buffers equilibrated to ambient field temperatures.

2. When calibrating or testing buffers in the field, place the buffer bottles in a mesh bag and suspend them in the ambient water long enough to allow them to equilibrate to temperature equilibrium. Alternatively, place the buffers in an insulated cooler filled with ambient water.

- When immersing buffer bottles in water, ensure that the bottle is firmly capped so that water cannot enter the bottle and contaminate the buffer.

3. For calibration in the laboratory or field, allow the buffers, temperature sensor, measurement vessel, and electrode to equilibrate to the same temperature.

4. Be careful not to fully submerge liquid-filled electrodes (keep the fill hole above the water surface) to prevent sample water from mixing with the filling solution.

5. Inspect the $\mathrm{pH}$ electrode.

a. Check for damage to the electrode bulb, body, and cables.

b. Rinse any mineral precipitate off the electrode with DIW.

c. Uncover the fill hole and ensure that the fillingsolution level is just below the fill hole. Keep the fill hole open to equalize the pressure inside and outside the electrode and to allow flow across the reference junction.

d. Add filling solution if needed.

e. If you can see small bubbles within the electrode solution (as typically occurs in a gel-filled electrode), gently shake the electrode body to dislodge them. Bubbles trapped in the sensing tip of the 
electrode will affect the physical conditions necessary for correct operation of the electrode. Do not wipe moisture from the glass bulb.

6. Turn on the $\mathrm{pH}$ meter. Note any error messages displayed by the meter during startup and record them in the $\mathrm{pH}$-meter/electrode logbook. Correct any error messages. Malfunctioning meters may require manufacturer attention.

7. Record in the pH-meter/electrode logbook any important or unusual startup information displayed by the $\mathrm{pH}$ meter. A calibration log may be paper or electronic, but is required for all calibrations and is helpful in tracking the performance of the electrode over time.

8. Initiate the calibration process by following the manufacturer's calibration instructions for the particular $\mathrm{pH}$ meter and electrode. Standard USGS procedure for calibration requires a two- or three-point calibration.

- Some $\mathrm{pH}$ instrument systems may use a different multipoint calibration procedure; in such cases, follow the instructions provided in the instrument manual.

- A single-point calibration, recommended by some manufacturers, is not acceptable for USGS field measurement of $\mathrm{pH}$.

USGS procedure for calibration of $\mathrm{pH}$ requires a two- or three-point calibration.

9. Record the temperature and value of $\mathrm{pH}$ buffers used at that temperature, with lot numbers and expiration dates, in the $\mathrm{pH}$-meter/electrode logbook.

10. Begin calibration procedures:

a. Note that the electrode and thermistor must be rinsed three times with DIW initially and between uses of each buffer.

b. If the meter does not specify a calibration order, begin with $\mathrm{pH} 7$.

c. To minimize contamination, each $\mathrm{pH}$ buffer should be stored in a dedicated, capped bottle that is refreshed with buffer before each field trip. The bottles should be labeled with the buffer value, lot number, and expiration date.

d. The calibration of the electrode should be performed in a small plastic or glass beaker that is dedicated to the $\mathrm{pH}$ calibration. e. Rinse the electrode and thermistor with DIW by pouring the DIW directly over the electrode. Rinse the calibration beaker with DIW three times.

f. Rinse the electrode and thermistor with the first buffer by pouring the buffer directly over the electrode and discarding the solution to waste.

g. First and second rinse, pour swirl discard-Pour enough buffer into the dedicated beaker so that it covers the electrode reference junction and some of the electrode body but does not cover the fill hole. The fill hole should be uncovered and open to the air. Immerse the electrode in the buffer solution; swirl the buffer to rinse the electrode body from above the reference junction to the bottom of the bulb. Discard the buffer appropriately. Repeat this step for a total of two times.

h. Third rinse, pour sit discard-Pour the next aliquot of buffer into the beaker and immerse the electrode in the buffer for 1 minute. Discard the buffer appropriately.

i. Pour sit measure - Pour fresh buffer into the beaker. Immerse the electrode, gently swirl to remove all air bubbles surrounding it, and allow it to sit for 1 minute.

j. Begin the calibration process for the buffer. Once the reading has stabilized, record the $\mathrm{pH}$ measurement (and [or] millivolts) in the $\mathrm{pH}$ meter/electrode logbook, along with the buffer temperature reading and the $\mathrm{pH}$ value from the buffer and temperature table.

11. For calibration with the additional $\mathbf{p H}$ buffer or buffers necessary to bracket the expected measurement, repeat step 10 above. Record all the calibration data, including the millivolt and slope readings, in the $\mathrm{pH}$ meter/electrode logbook (see step 12 to test the adequacy of the calibration using the slope test or millivolt test).

12. At this point, the electrode should be calibrated. Check the adequacy of the calibration and that the electrode is functioning properly by using the slope test and the millivolt test. Some instruments can display the slope value; this value should be recorded in the $\mathrm{pH}$-meter/ electrode logbook.

- The slope test—Properly working electrodes should have slopes that are 56.2 to $59.8 \mathrm{mV} / \mathrm{pH}$ unit at $25^{\circ} \mathrm{C}$, which is 95 to 101 percent of the expected slope from the theoretical Nernst relation (Busenberg and Plummer, 1987). If the slope or percent value is outside this range, first clean the electrode and check: the level of the filling solution, that the fill hole is open, and that the junction is free flowing; then, recalibrate. 
- To calculate the slope in units of millivolts per $\mathrm{pH}$ unit for a two-point calibration at $25^{\circ} \mathrm{C}$ :

slope $=\frac{(\text { millivolts of buffer } 1-\text { millivolts of buffer } 2)}{(\mathrm{pH} \text { of buffer } 2-\mathrm{pH} \text { of buffer } 1)}$

and the slope as a percentage of the expected slope from the theoretical Nernst relation at $25{ }^{\circ} \mathrm{C}$ is

$$
\text { slope }(\text { in percent })=\frac{\text { slope }}{59.16} \times 100
$$

This straightforward calculation of slope and relative slope is valid only at $25^{\circ} \mathrm{C}$ because the expected slope from the theoretical Nernst relation varies with temperature. For example, the Nernstian slope is $55.18 \mathrm{mv} / \mathrm{pH}$ unit at $5{ }^{\circ} \mathrm{C}$ and $64.12 \mathrm{mV} / \mathrm{pH}$ unit at $50{ }^{\circ} \mathrm{C}$ (Bates, 1965). To calculate relative slope at a temperature other than $25^{\circ} \mathrm{C}$, the value for the theoretical Nernst response must be substituted for 59.16 in the equation.

- The millivolt test - For $\mathrm{pH}$ meters that display and store millivolt readings, troubleshoot a suspect electrode or calibration by using the following guidelines to determine adequate voltage potentials for each buffer:

- pH 10.01 buffer: readings between -192 and $-162 \mathrm{mV}$

- pH 7.00 buffer: readings between -15 and $15 \mathrm{mV}$

- pH 4.01 buffer: readings between 162 and $192 \mathrm{mV}$

- pH 1.68 buffer: readings between 300 and $330 \mathrm{mV}$

- The meter may not recognize the $\mathrm{pH}$ buffer or may incorrectly identify the $\mathrm{pH}$ buffer if the millivolt response is outside the acceptable range. The acceptable range may vary with the manufacturer.

- If buffers other than the standard pH 1.68, 4.01, 7.00, and 10.01 buffers are used, refer to the information provided with the specific buffer lot to determine the correct, temperature-compensated $\mathrm{pH}$ value for that buffer. Buffers other than $\mathrm{pH} 1.68,4.01,7.00$, and 10.01 should be used for calibration only in cases where expected measured $\mathrm{pH}$ is less than 1.68 or greater than 10 , or if the $\mathrm{pH}$ meter specifically requires their use.

13. Clean, recondition, or replace the electrode if, after recalibration, the slope remains outside the acceptable range of 95 to 101 percent or the acceptable range of the millivolt response is not met at any of the calibration points.

\section{TECHNICAL NOTE:}

After calibration, measure the $\mathrm{pH}$ of the final $\mathrm{pH}$ buffer and check that the measured $\mathrm{pH}$ at the calibration temperature is within $0.05 \mathrm{pH}$ units of the certified value (table 6.4-3).

- If the measured $\mathrm{pH}$ is equal to or within 0.05 $\mathrm{pH}$ units of the certified value, proceed with the sample measurement.

- If the measured $\mathrm{pH}$ is more than $\pm 0.05 \mathrm{pH}$ units from the certified value, recalibrate the $\mathrm{pH}$ electrode or determine whether the electrode is not functioning properly and should be reconditioned or replaced.

\subsubsection{Calibration of the pH Sensor in Multiparameter Sondes}

Before beginning calibration of the $\mathrm{pH}$ electrode in a multiparameter sonde, carefully read and follow the manufacturer's instructions. Guidelines that incorporate USGS protocols for $\mathrm{pH}$ calibration and measurement using multiparameter sondes also are described in NFM A6.8.

\section{General procedures for calibration of the $\mathrm{pH}$ sensor on a multiparameter sonde-}

1. Calibrate the sonde in a controlled environment such as a laboratory. Most modern multiparameter sondes automatically compensate for temperature differences and have acceptable accuracy under normal field conditions for temperatures ranging from 5 to $35^{\circ} \mathrm{C}$ and for $\mathrm{pH}$ measurements ranging from 4.0 to 9.5 .

- Verify the calibration with measurements of buffers at ambient field temperatures. Do this regularly to verify temperature compensation over the range of temperatures at the site.

2. Select the $\mathrm{pH}-7$ buffer and one or two (depending on the meter) additional buffer solutions that will bracket the anticipated $\mathrm{pH}$ of the sample. Allow the temperature of the buffers and probes on the sonde to equilibrate.

3. Rinse the sonde, calibration cup, and electrode thoroughly three times with DIW before the calibration and three times with DIW and buffer solution between measurement of each buffer solution.

4. Rinse the calibration cup, and $\mathrm{pH}$ and temperature sensors, three times with separate aliquots of the first $\mathrm{pH}$ buffer, using the "pour-swirl-discard twice, poursit-discard, pour-sit-measure" method described in section 4.1.1, step 10.

5. Repeat step 4, using additional $\mathrm{pH}$ buffers, and lock in the calibration points. (Depending on site conditions and study objectives, it might be useful to check the calibration range of the $\mathrm{pH}$ sensor by using an additional buffer; if appropriate, lock in the third buffer value.) 
6. Always record temperature, buffer lot numbers, and expiration dates with calibration information in the $\mathrm{pH}$ meter/electrode logbook.

\subsection{Measurement of $\mathrm{pH}$}

Standard procedures for $\mathrm{pH}$ measurement are expected to yield accurate sample $\mathrm{pH}$ measurements for waters with specific conductance between 100 and $60,000 \mu \mathrm{S} / \mathrm{cm}$, temperature from 0 to $90^{\circ} \mathrm{C}$, and $\mathrm{pH}$ from 1.68 to 10 . Some of the procedures will need to be amended to accurately measure $\mathrm{pH}$ at the extremes of these ranges, but standard $\mathrm{pH}$ calibrations and combination $\mathrm{pH}$ electrodes can be appropriately used to achieve an accurate $\mathrm{pH}$ measurement of environmental waters whose characteristics fall within these ranges. Studies of waters whose properties fall outside the ranges described above (low-ionic-strength waters and [or] waters with $\mathrm{pH}$ less than 1.68 or greater than 10) require further modifications of $\mathrm{pH}$ calibration or measurement procedures.

The $\mathrm{pH}$ of sample water should be measured in situ or as soon as possible after removal of the sample from its environmental source. The $\mathrm{pH}$ of a water sample can change substantially within hours or even minutes after sample collection as a result of temperature change; changes in concentrations of gases (carbon dioxide, hydrogen sulfide, ammonia); changes in redox conditions; mineral precipitation; metabolic respiration by microorganisms; and other chemical reactions, physical changes, and biological activity (Hem, 1989). Field conditions, including rain, wind, cold, heat, dust, direct sunlight, and direct exposure to vehicle exhaust, can cause measurement problems. Always protect the instrument system and the measurement process from the effects of harsh weather and transportation damage.

In addition to potential changes in the composition of the sample water, the reliability of $\mathrm{pH}$ measurements depends on the accuracy of the calibration, and temperature measurement. The physical limitations and characteristics of the electrode, including response time, liquid junction potentials, and drift, can affect the accuracy of the $\mathrm{pH}$ measurement.

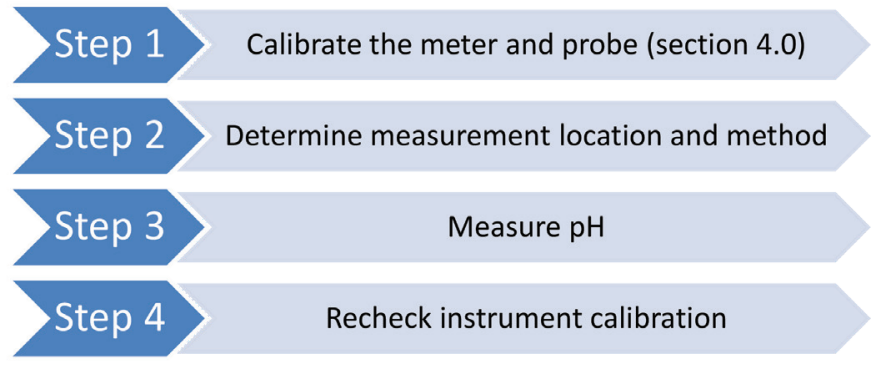

Figure 6.4-3. Procedure: Steps for making measurements of $\mathrm{pH}$.

\subsection{Making the pH Measurement}

To measure $\mathrm{pH}$, follow the steps in the procedure outlined in figure 6.4-3. Details for each step in the procedure are provided below.

\section{Step 1. Calibrate the pH meter and probe (section 4.0).}

Single-parameter $\mathrm{pH}$ meters and electrodes or multiparameter instruments used for discrete sampling are required to be calibrated on the day of use and to be checked at each field site to ensure that the calibration is stable. The frequency of calibration is determined by the stability of the meter. Typically, the calibration should be done in a controlled laboratory environment. Most modern meters have built-in temperature compensation that works well in the temperature range from 5 to $35^{\circ} \mathrm{C}$ and $\mathrm{pH}$ from 4.0 to 9.5 , but this assumption should be checked regularly with buffers that are equilibrated to ambient field-sample temperatures. See section 4.0 for information about and procedures for meter and electrode calibration for $\mathrm{pH}$ measurements.

\section{Step 2. Determine the location and method for the $\mathrm{pH}$ measurement.}

1. The $\mathbf{p H}$ of surface water can be determined-

- in situ from a single point or a cross sectional measurement; document the method in field notes and see point 3 below.

- from a sample that is withdrawn from a churn or cone splitter or other approved samplecompositing device.

- by using a pumping system with a flow-through cell or chamber.

2. It is not advisable to immerse the $\mathrm{pH}$ electrode into fastflowing surface water for the following reasons-

- Placing the $\mathrm{pH}$ electrode into fast-flowing water risks damage to the delicate glass bulb (scratching, pitting, coating), which will inhibit the correct functioning of the electrode.

- Proper functioning of the glass bulb membrane is affected when equilibrium is not achieved with the surrounding sample solution especially if cavitation occurs around the electrode.

- Reference-junction equilibrium can be affected by rapidly moving water. 
3. If a sample is collected with depth/width-integrated methods, the $\mathrm{pH}$ should be representative of the composited sample, not a point measurement. Before collecting the sample and making measurements, determine the range and variability of physical parameter values in the cross section by using an in situ measurement method (for example, a multiparameter sonde).

4. The final reported $\mathrm{pH}$ of groundwater should be measured under quiescent sample conditions with equipment that minimizes aeration and changes in chemical composition and temperature. If possible, operate equipment in a manner that minimizes the exchange of dissolved gases between the sample and the atmosphere.

- When a single-parameter meter is used, the measurement can be made either (a) with the $\mathrm{pH}$ electrode and temperature sensor inserted into an airtight, flow-through cell or chamber to which the sample is pumped; or (b) in an open vessel that contains an aliquot of sample either collected from pump discharge or withdrawn from the well with a sampling device.

- The flow-through cell method yields accurate pH data when implemented appropriately. Flowthrough cells are available for use with individual probes (fig. 6.4-4A) and with multiparameter sondes (fig. 6.4-4B).

- Bailing or other methods for collecting discrete samples for $\mathrm{pH}$ measurement must be implemented carefully to minimize temperature change, turbulence, and sample aeration resulting from decanting and mixing of the bailed water.
5. If a flow-through cell system is used to measure $\mathrm{pH}$ (groundwater or surface water) -

- Keep the cell as close to the source water as possible and shield the cell and tubing from direct sunlight and precipitation.

- Check that the electrode fill hole is open and not submerged and that the reference junction is entirely submerged.

- Check for and eliminate any back-pressure condition in the cell.

- Monitor $\mathrm{pH}$ stability during well purging. Record $\mathrm{pH}$ values at regularly spaced time intervals throughout purging.

- During purging, keep the flow to the cell constant. The flow should be fast enough to keep sediment in suspension, but not so fast that the sample is aerated or cavitation occurs around the electrode.

- When purging has ended and the final $\mathrm{pH}$ measurement is made, divert flow away from the flowthrough cell to measure $\mathrm{pH}$ in a quiescent condition.

- Any static electrical charge on the inside of the well casing or borehole may be transferred to the $\mathrm{pH}$ electrode, a condition sometimes referred to as a "ground loop," which may compromise accurate $\mathrm{pH}$ measurement. Ground loops are rare. When they exist, electrodes commonly read accurately in buffers but give erroneous, fluctuating readings in the flow-through cell/chamber.
Figure 6.4-4. Photographs of $(A)$ a flow-through cell/ chamber for use with multiple sensors, shown without sensors installed; and $(B)$ a flow-through cell for a multiparameter sonde. (Photographs from $(A)$ Geotech Environmental Equipment, Inc., accessed February 13, 2020, at http://www.geotechenv.com/ flowblock_monitoring_system. html, and (B) YSI Inc., accessed February 13, 2020, at https:// www.ysi.com/accessory/ id-005083/5083-flow-cell.)
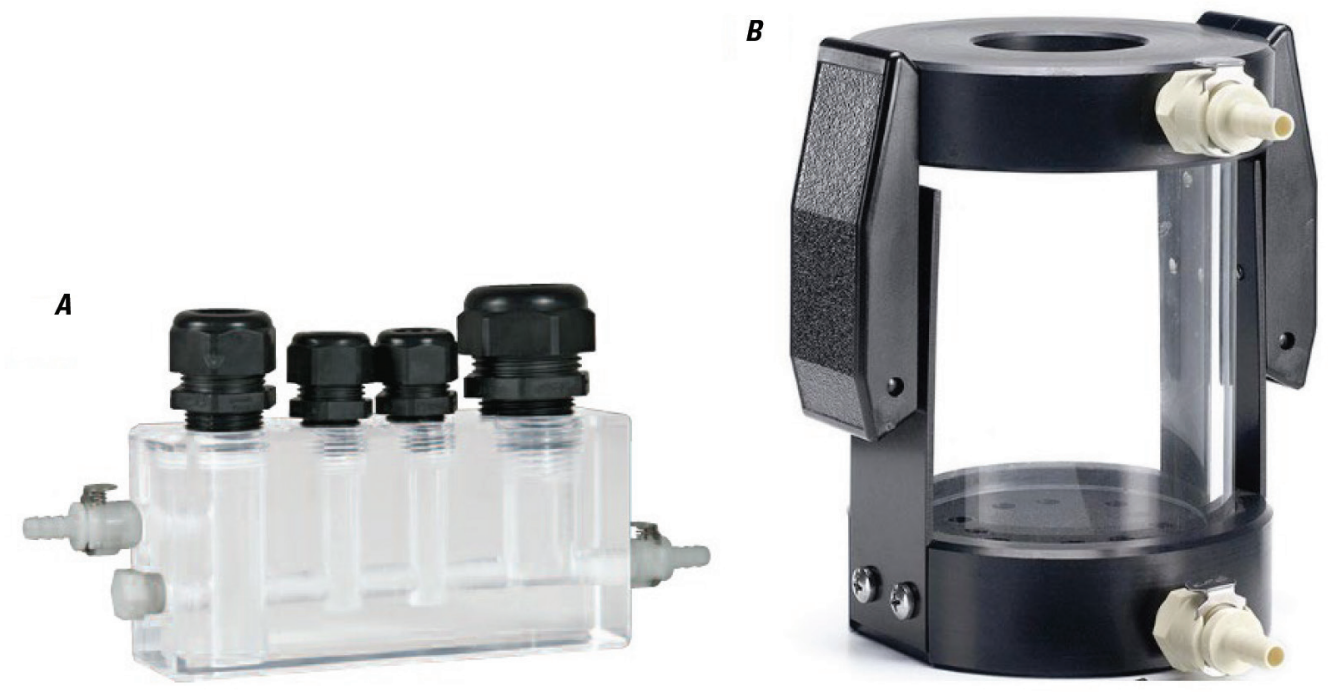
Document the sampling method used to obtain measurements of $\mathrm{pH}$ on field forms.

\section{Step 3. Measure pH}

1. Set up the $\mathrm{pH}$ instrumentation at the sampling site.

2. Measurements of $\mathbf{p H}$ in a sample vessel such as a beaker or other container-

a. Fill the sample vessel with sufficient sample to ensure that the electrode reference junction can be fully immersed without submerging the fill hole, taking care not to aerate the sample. Use only clean measurement vessels.

\section{b. First and second rinse in sample solution-} Immerse the electrode and thermistor in the sample; swirl to rinse the electrode body from above the reference junction to the bottom of the bulb. Discard the sample appropriately. Be careful not to submerge the fill hole. Repeat this step for a total of two times.

c. Third rinse-Pour the next aliquot of sample into the vessel and immerse and swirl the electrode in the sample for 1 minute. Discard the waste sample appropriately.

d. Refill the vessel with another aliquot of samplePlace the electrode in the sample and swirl gently to equilibrate, making sure that no bubbles are trapped against the $\mathrm{pH}$ bulb and the glass bulb of the electrode does not contact the sides or bottom of the measurement vessel.

e. Stop swirling and allow the sample to be quiescent before recording $\mathrm{pH}$.

3. Measurements in a flow-through cell or chamber system-

a. Connect the flow-through cell with probes installed to the pumping system and begin pumping to purge.

b. Allow the system to purge and the sensors to equilibrate with the water for 5 minutes or more.

c. Stop the pump or divert flow from the cell to allow the water in the chamber to become quiescent to record the final measurement of $\mathrm{pH}$.

\section{In situ measurements of $\mathbf{p H}-$}

a. Rinse the electrode and thermistor thoroughly with DIW and then with the sample by pouring directly over the electrode and thermistor and appropriately discarding the rinse. b. Place the electrode into the water. If a singleparameter $\mathrm{pH}$ instrument with refillable electrode is being used, be sure to keep the fill hole above the water surface.

c. If the water body being measured in situ is not moving, gently swirl the electrode and allow the electrode and water to equilibrate for at least 1 minute and until the reading stabilizes.

d. Stop swirling and allow the sample to become quiescent to record $\mathrm{pH}$. Conditions of flow over the electrode should be recorded if the water is moving.

5. Record the final $\mathbf{p H}$, millivolts (if available), and temperature under quiescent sample conditions if possible when the reading stabilizes.

- A pH value is assumed to be stable when three to five readings made at regularly spaced intervals are within $\pm 0.1 \mathrm{pH}$ units. If measurements continue to fluctuate outside the acceptable range, continue to monitor, or, if site conditions are demonstrably variable (degassing, rapid thermal changes due to mixing of water at depth), select the median of three or more measurements made within about 60 seconds as the value to record.

- If the $\mathrm{pH}$ measurement does not stabilize and continually drifts in one direction, record the final measurement. If the $\mathrm{pH}$ measurement does not stabilize and varies around a single value, record the median of three or more separate measurements from a quiescent sample if possible.

- Record the final $\mathrm{pH}$ value of the sample to the nearest $0.01 \mathrm{pH}$ unit. Rounding of $\mathrm{pH}$ measurements will depend on the accuracy and precision of the equipment.

- Always record the temperature of the sample concurrently with the $\mathrm{pH}$ measurement.

- Record the sample $\mathrm{pH}$ on the analytical service request forms that will accompany the samples being shipped to the laboratory, as this value is used in many analyses.

6. Between calibrations and measurements of different samples, rinse the electrode and thermistor with DIW and then again with the new sample or buffer. This step must always be completed between different solutions.

Always record the temperature of the sample concurrently with each pH measurement. 


\section{Step 4. Recheck instrument calibration.}

Check the stability of the $\mathrm{pH}$ meter and electrode in the field by measuring the $\mathrm{pH}$ of the buffer whose $\mathrm{pH}$ is nearest to that of the samples. If the $\mathrm{pH}$ of the buffer differs by more than $0.05 \mathrm{pH}$ units from the certified value at the measured temperature (table 6.4-3), recalibrate the $\mathrm{pH}$ system and then remeasure the $\mathrm{pH}$ of the sample.

\subsection{Measurement of $\mathrm{pH}$ in Waters with Low Specific Conductance}

Accurate and precise measurement of $\mathrm{pH}$ in low-specificconductance waters (less than $100 \mu \mathrm{S} / \mathrm{cm}$ ) is challenging because (1) the water is not sufficiently conductive to complete the electrical circuit and allow for a stable $\mathrm{pH}$ reading using a combination $\mathrm{pH}$ electrode, (2) differences in ionic strength between the sample and buffers are large, and (3) the potential of the liquid junction is larger than normal. Modern reference junctions are designed to decrease the effects of low specific conductance, but may not always produce the desired accuracy for measurements of $\mathrm{pH}$. Low-resistance glass $\mathrm{pH}$ electrodes or reference junctions with a fast, continuous leak rate can be used to make accurate measurements of $\mathrm{pH}$ in low-ionicstrength waters; however, because these electrodes are expensive, generally are not designed for fieldwork, and only work well in dilute waters, they do not replace traditional electrodes. Some methods recommend calibrating with low-ionic-strength buffers to minimize liquid junction potential errors, but these buffers are easily contaminated and should be avoided in field settings.

The recommended method allows for using normal $\mathrm{pH}$ field electrodes and standard $\mathrm{pH}$ buffers (table 6.4-3) by adding a small amount of potassium chloride $(\mathrm{KCl})$ to a subsample of water to increase the specific conductance by approximately $150 \mu \mathrm{S} / \mathrm{cm}$. Increasing the specific conductance by this amount has little effect on the hydrogen ion activity coefficient; the $\mathrm{pH}$ is expected to be affected by less than $0.01 \mathrm{pH}$ units (Busenberg and Plummer, 1987). It is first recommended to determine the $\mathrm{pH}$ by using the procedures described in section 5.1. If the sample $\mathrm{pH}$ does not stabilize, and the specific conductance is less than $100 \mu \mathrm{S} / \mathrm{cm}$, then the following procedure is recommended:

1. Before going to the field, prepare small glass vials containing 20 milligrams (mg) of dry potassium chloride $(\mathrm{KCl}$ - crystalline, American Chemical Societycertified). Prepare more vials than the expected number of $\mathrm{pH}$ measurements. (Note: Addition of other salts [for example, sodium chloride] also will increase the specific conductance, but $\mathrm{KCl}$ is recommended to minimize effects on the liquid junction potential.)

2. At the sample site, fill a $250-\mathrm{mL}$ polyethylene bottle with raw sample water. Immediately transfer $20 \mathrm{mg} \mathrm{KCl}$ to the sample solution, cap the solution to minimize transfer of gases, and gently swirl the bottle to dissolve the
$\mathrm{KCl}$. Maintain the sample at ambient temperature. This procedure will increase the specific conductance of the sample by approximately $150 \mu \mathrm{S} / \mathrm{cm}$.

3. Measure the $\mathrm{pH}$ on an aliquot of the $\mathrm{KCl}$-amended sample from the $250-\mathrm{mL}$ bottle following the procedure in section 5.1 and record the addition of $\mathrm{KCl}$ to the sample in the field notes.

\subsection{Quality Assurance/Quality Control for Measurements of $\mathrm{pH}$}

Field measurements, like all measurements of water quality, require quality assurance to validate the accuracy and precision of the data. For measurement of $\mathrm{pH}$, quality assurance includes documentation of meter calibration and performance, proficiency testing of technicians, collection and measurement of replicate samples to estimate variability, and timely review of results to validate the data.

Replicate samples for quality assurance of $\mathrm{pH}$ measurements are collected on a schedule specified in the project data-management plan. Replicates for $\mathrm{pH}$ measurement should be collected at least annually, and more frequently if needed. Replicates in the field can be sequential, whereby multiple samples are collected in the field and measured for $\mathrm{pH}$, or can be concurrent, whereby the $\mathrm{pH}$ of a water sample is measured and measured again after the instrument is checked and recalibrated if needed. Replicate data are used to document the precision of $\mathrm{pH}$ measurements in the field and to verify the stability of the meter and probe.

Another check for $\mathrm{pH}$ measurements is to send a split sample to the USGS National Water-Quality Laboratory (NWQL) to compare its $\mathrm{pH}$ to that measured in the field. Changes in temperature, gas composition, and redox conditions could cause changes in chemistry, but this check can still provide useful information about the stability of the water quality of the sample.

USGS field personnel are required to participate in the National Field Quality Assurance (NFQA) program. This program, conducted annually by the USGS Quality Systems Branch (QSB), provides blind samples for measurement of $\mathrm{pH}$, specific conductance, and alkalinity to field personnel for testing. Field personnel measure the NFQA samples during their regular sampling routine and can compare their results with most probable values. When measurements are outside established control limits, the tests are repeated, possible reasons for the errors are investigated, and the technicians are retrained to improve their techniques.

Results of measurements made on quality-control samples are stored in the USGS National Water Information System (NWIS) database. 


\subsection{Reporting}

Due to the array of reactions that can change the $\mathrm{pH}$ in environmental samples, the effect of temperature on the operation of the $\mathrm{pH}$ instrument system, and easily changed chemical and microbiological equilibria within the sample, $\mathrm{pH}$ measurements are required to be completed and recorded at the field site in situ or as soon as possible after removing the sample from the environmental medium.

Most meters measure with precision in the range of \pm 0.01 units. Modern meters and multiparameter sondes can sometimes discern environmental patterns within this range. Therefore, $\mathrm{pH}$ should be recorded on field sheets to $\pm 0.01 \mathrm{pH}$ units. Accuracy of $\mathrm{pH}$ measurements is greater at lower values of $\mathrm{pH}$ because hydrogen ion activity is greater. Accuracy of $\mathrm{pH}$ measurements is poorer at higher values of $\mathrm{pH}$ because the activity of hydrogen ions is lower.

\section{When recording $\mathrm{pH}-$}

- Record the method that was used to make the $\mathrm{pH}$ measurement, as well as the date and serial numbers or other identifiers for the meter and electrode.

- Record environmental measurements on field sheets and in NWIS to \pm 0.01 standard $\mathrm{pH}$ units, if the meter provides this level of precision.

- Rounding for reporting purposes will depend on the accuracy and precision of the equipment and is typically to three significant figures. Rounding to \pm 0.01 units at low and neutral ranges of $\mathrm{pH}$, and to \pm 0.1 units for $\mathrm{pH}$ values equal to or greater than 10.0 , is recommended. The accuracy and precision of the readings for each meter should be defined further with calibration checks and quality-control sampling.

- Always record temperature with measurements of $\mathrm{pH}$.

\subsection{Troubleshooting}

Consult the instrument manufacturer for recommended troubleshooting actions for specific single-parameter and multiparameter $\mathrm{pH}$ instrument systems. Many problems encountered during $\mathrm{pH}$ calibration and measurement can be attributed directly to the condition and responsiveness of the $\mathrm{pH}$ electrode. Depending on use, the typical useful life expectancy of $\mathrm{pH}$ electrodes used in environmental field operation is approximately 12 to 18 months. With time, $\mathrm{pH}$ electrodes need to be evaluated more frequently to determine whether the deviation of the millivolt response slope falls outside the acceptable response of 95 to 101 percent of the ideal response slope in NIST-traceable buffers. Replace the $\mathrm{pH}$ electrode when the response falls outside the acceptable range for the response slope and the deviation cannot be corrected through cleaning or reconditioning. Also, for any problem encountered, first check that the instrument batteries are fully charged, and keep spare fresh batteries on hand.

Table 6.4-4 provides a general guide for troubleshooting $\mathrm{pH}$ meters, electrodes, and multiparameter sondes. 
Table 6.4-4. Troubleshooting guide for $\mathrm{pH}$ measurement.

[Modified from Ritz and Collins, 2008; DIW, deionized water; NIST, National Institute of Standards and Technology]

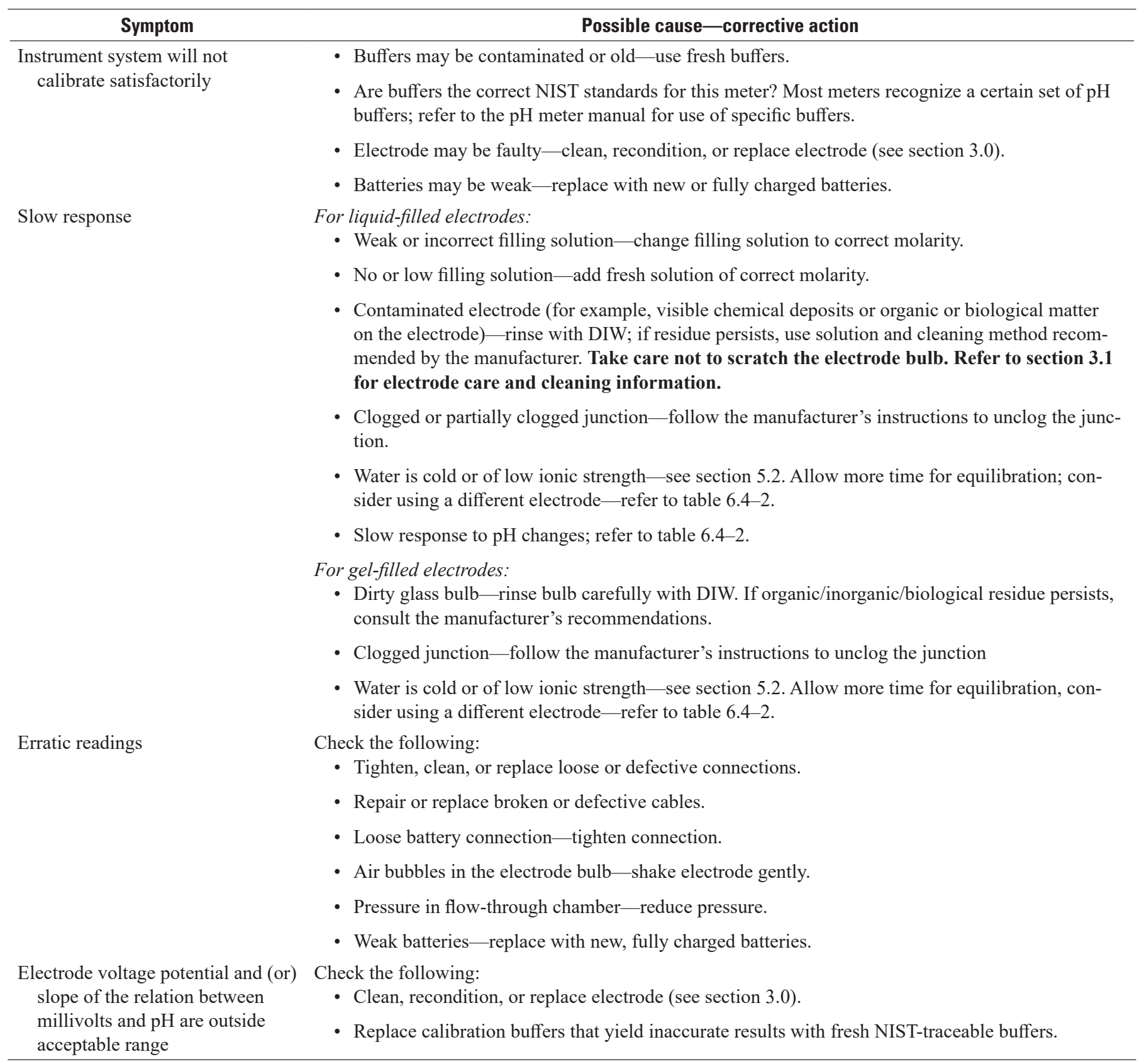




\section{Acknowledgments}

The information in the U.S. Geological Survey (USGS) National Field Manual (NFM) is based on existing manuals, various reference documents, and a broad spectrum of expertise provided by USGS colleagues. Authors of previous versions of NFM chapter A6.4 were Eurybiades Busenberg, J.A. Collins, J.K. Kurklin, D.B. Radtke, G.F. Ritz, and F.D. Wilde. The persistence and spirit that all of our colleagues brought to the development of a national field manual were invaluable.

The following USGS colleagues provided content and detailed reviews that improved the technical quality of this report: Blaine McCleskey, Cherie Miller, Gerolamo Casile, Leslie DeSimone, Jacob Gibs, Andrew Hickey, William Mcbride, Teri Snazelle, Katie Walton-Day. Editorial and production assistance from Marilyn Billone, Sandy Cooper, Elizabeth Good, Cathy Knutson, Katharine Schindler, and Dale Simmons is greatly appreciated. These individuals contributed to the accuracy, quality, and usability of the NFM, and demonstrated much patience as we traversed the difficult task of developing the new format.

Special thanks are extended to Franceska Wilde (USGS), who led the effort for the NFM from its inception until her retirement in 2014; the USGS NFM Steering Committee (Gerolamo Casile, Alissa Coes, Michael Manning, Cherie Miller, Timothy Oden, Lisa Olsen, Michael Rosen, and Stanley Skrobialowski; Cherie Miller, who led the effort from 2016 to 2018; and Gerolamo Casile, who assumed responsibility for the NFM in 2018.

\section{Selected References}

Bates, R.G., 1973, Determination of $\mathrm{pH}$, theory and practice (2d ed.): New York, John Wiley and Sons, Inc., 435 p.

Benjamin, M.M., 2015, Water chemistry (2d ed.): Long Grove, Ill., Waveland Press, Inc., 905 p.

Buck, R.P., Rondinini, S., Covington, A.K., Baucke, F.G.K., Brett, C.M.A., Camoes, M.F., Milton, M.J.T., Mussini, T., Naumann, R., Pratt, K.W., Spitzer, P., and Wilson, G.S., 2002, Measurement of $\mathrm{pH}$-Definition, standards, and procedures (IUPAC recommendations 2002): Pure and Applied Chemistry, v. 74. no. 11, p 2169-2200.

Busenberg, E., and Plummer, L.N., 1987, pH measurement of low-conductivity waters: U.S. Geological Survey Water-Resources Investigations Report 87-4060, 21 p., https://pubs.usgs.gov/wri/1987/4060/report.pdf.
Gibs, Jacob, Wilde, F.D., and Heckathorn, H.A., 2012, Use of multiparameter instruments for routine field measurements (ver. 1.1): U.S. Geological Survey Techniques of Water-Resources Investigations, book 9, chap. A6, section 6.8, accessed February 13, 2020, at https://pubs.er.usgs.gov/ publication/twri09A6.8.

Hem, J.D., 1989, Hydrogen-ion activity, in Study and interpretation of the chemical characteristics of natural water (3d ed.): U.S. Geological Survey Water-Supply Paper 2254, p. 61-66, accessed February 12, 2020, at https://doi.org/10.3133/wsp2254.

Mottl, M.J., 2009, Highest pH?: Geochemical News, v. 141, accessed February 12, 2020, at https://www.geochemsoc.org/ publications/geochemicalnews/gn141oct09/highestph.

Nordstrom, D.K., 1997, Geochemistry for groundwater systems: U.S. Geological Survey Training Course given at the USGS National Training Center, Denver, Colo., March 1997.

Nordstrom, D.K., and Alpers, C.N., 1999, Negative pH, efflorescent mineralogy, and consequences for environmental restoration at the Iron Mountain Superfund site, California: Proceedings of the National Academy of Sciences, v. 96, p. 3455-3462, https://doi.org/10.1073/pnas.96.7.3455.

Ritz, G.F., and Collins, J.A., 2008, pH (ver. 2.0, October 2008), in National field manual for the collection of water-quality data: U.S. Geological Survey Techniques of Water-Resources Investigations, book 9, chapter A6.4, accessed February 13, 2020, at https://pubs.water.usgs.gov/ twri9A6.4.

Robinson, R.A., and Stokes, R.H., 1959 Electrolyte solutions: London, Butterworths Publications Limited, 571 p.

U.S. Geological Survey, 2018, General introduction for the "National Field Manual for the Collection of WaterQuality Data" (ver. 1.1, June 2018): U.S. Geological Survey Techniques and Methods, book 9, chap. A0, https://doi.org/10.3133/tm9A0.

U.S. Geological Survey, variously dated, National field manual for the collection of water-quality data: U.S. Geological Survey Techniques of Water-Resources Investigations, book 9, chaps. A1-A10. (Also available at http://pubs.water.usgs.gov/twri9A.) 




\section{$\frac{\mathbb{2}}{\mathrm{C}}$}

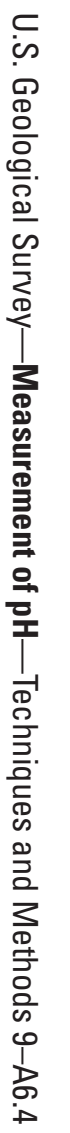

